\section{D) Check for updates}

Cite this: Dalton Trans., 2017, 46 , 8146

Received 2nd May 2017, Accepted 30th May 2017

DOI: $10.1039 / c 7 d t 01605 k$ rsc.li/dalton

\title{
The isomeric structure of pentacoordinate chiral spirophosphoranes in solution by the combined use of NMR experiments and GIAO DFT calculations of NMR parameters $\dagger$
}

\author{
Fedor M. Polyancev, (D) Kirill E. Metlushka, Dilyara N. Sadkova, Zilya R. Khisametdinova, \\ Olga N. Kataeva, Vladimir A. Alfonsov, Shamil K. Latypov (D) * and Oleg G. Sinyashin (DD
}

\begin{abstract}
The interplay of NMR experiments and DFT calculations of NMR parameters is a reliable method for determining the relative configurations of pentacoordinate chiral spirophosphoranes bearing two six- or five-membered rings at the phosphorus atom in solution. The major product of the Betti based derivatives corresponds to the isomers with both substituents at chiral carbons being opposite to the $\mathrm{P}-\mathrm{H}$ proton. The next populated product corresponds to the isomer with different chiralities at carbons. The least populated isomer is one with both substituents being at the same side of the heterocycle as the $\mathrm{P}-\mathrm{H}$ bond.
\end{abstract}

\section{Introduction}

Chiral phosphorus compounds are widely used in stereoselective synthesis. ${ }^{1-5}$ For example, chiral phosphorus ligands are of importance in the design of catalysts for asymmetric homogeneous catalysis. ${ }^{6}$ Pentacoordinate phosphorus compounds have drawn special attention for their role as intermediates in some biological processes (e.g. enzymatic phosphoryl transfer reactions, ${ }^{7-29}$ hydrolysis/formation of DNA, RNA, cyclic AMP)..$^{30,31}$

Their structural and dynamic properties strongly correlate with the reactivity/selectivity of the processes they are involved in. Although the knowledge about the stereochemistry (the absolute and relative configurations) of these compounds is important in understanding these processes, very few structural studies of pentacoordinate phosphorus systems have been published so far. ${ }^{32-38}$

Pentacoordinate phosphoranes with an asymmetric phosphorus atom and with several additional chiral chelate ligands are especially difficult to analyze, since these chiral centers may generate a variety of stereoisomers and the determination of their fine structure is not straightforward. To this end X-ray single crystal investigations could be helpful, but obtaining

A.E. Arbuzov Institute of Organic and Physical Chemistry, Kazan Scientific Center, Russian Academy of Sciences, Arbuzov str. 8, Kazan, 420088, Russian Federation. E-mail: lsk@iopc.ru

$\dagger$ Electronic supplementary information (ESI) available: 1D/2D NMR spectra and calculated data for 4-6. CCDC 1542633 and 1542634. For ESI and crystallographic data in CIF or other electronic format see DOI: 10.1039/c7dt01605k good single crystals is often time consuming and sometimes impossible. This point, coupled with the fact that most chemical reactions and biological processes occur in solution, makes it highly desirable to find an alternative, reliable, and easy way to determine the relative configurations of such hypervalent chiral phosphorus compounds directly in solution. ${ }^{33-38}$

Progress in NMR correlation techniques and the state-ofthe-art density functional theory (DFT) calculations of NMR parameters has emerged in recent years as a very powerful tool for fine structural analysis of organic compounds and biomolecules. There are a number of examples when DFT calculations of NMR ${ }^{1} \mathrm{H},{ }^{13} \mathrm{C}$ and ${ }^{15} \mathrm{~N}$ parameters in the frame of the GIAO method allowed the establishment of tautomeric, isomeric and conformational structures as well. ${ }^{39-53}$ However applications of similar approaches to analyze phosphorus compounds by DFT calculations of ${ }^{31} \mathrm{P}$ NMR parameters are very rare. ${ }^{54-56}$

The study here shows that the interplay of the NMR experiment and theory is a powerful method for determining the relative configurations of pentacoordinate chiral spirophosphoranes. For the illustration several pentacoordinate spirophosphoranes bearing two six-membered (Betti based derivatives) and five-membered ( $\alpha$-aminocarbonic acid derivatives) rings at the phosphorus atom were used.

\section{Results}

\section{Synthesis}

Three chiral elements (two centres and one axis) lead to the four possible combinations. In order to obtain the full set of 


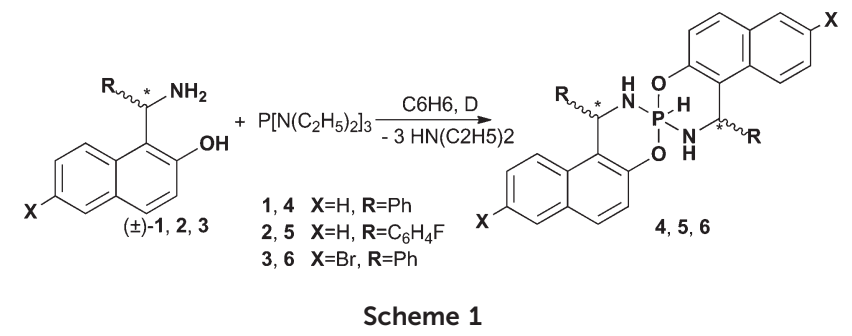

stereoisomers we used racemic Betti bases. The synthesis of $\mathrm{P}-\mathrm{H}$-spirophosphoranes was carried out by substituting the amino groups in the hexaethyltriamidophosphite by 1-( $\alpha$-aminobenzyl)-2-naphthols (Scheme 1$)$. For example, in the ${ }^{31} \mathrm{P}\left\{{ }^{1} \mathrm{H}\right\}$ NMR spectra of the reaction mixture of 4 there are two signals with the chemical shifts (CS) characteristic of phosphoranes $(-75.4(65 \%)$ and $-76.7(35 \%) \mathrm{ppm})$ that may be attributed to the formation of two isomers.

In contrast to the dominant product $\left(\delta^{31} \mathrm{P}=-75.4 \mathrm{ppm}\right)$, the ${ }^{1} \mathrm{H}$ spectra of which correspond to the high symmetry structure, the second component apparently has no symmetry, and two spiro halves of phosphorane 4 differ in the ${ }^{1} \mathrm{H}$ NMR spectrum. When diethylamine hydrochloride is used as the catalyst, these two isomers could be obtained in an about $1: 1$ ratio and their isolation in individual form becomes possible via crystallization. It is interesting that after about 4-6 hours in the NMR spectrum of the individual product that was major in the initial reaction mixture $\left(\delta^{31} \mathrm{P}=-75.4 \mathrm{ppm}\right)$, additional signals appeared which can also be attributed to the structure of high symmetry $\left(\delta^{31} \mathrm{P}=-80.7 \mathrm{ppm}\right)$ with two spiro-connected six-membered heterocycles being equivalent in the ${ }^{1} \mathrm{H}$ NMR spectra.

In a similar manner for $\mathbf{5}$ the formation of two isomers was observed which were separated and analyzed (Fig. 1a and b). In this case the ${ }^{19} \mathrm{~F}$ NMR is particularly useful and allows distinguishing symmetrical (one singlet, $\delta^{19} \mathrm{~F}=-116 \mathrm{ppm}$ ) and non-symmetrical (two singlet's of equal intensity, $\delta^{19} \mathrm{~F}=$ -115.8 and $\delta^{19} \mathrm{~F}=-116.6 \mathrm{ppm}$ ) isomers. The monitoring of the major isomer 5a via the ${ }^{1} \mathrm{H}$ and ${ }^{31} \mathrm{P}$ NMR showed that after some time an additional product appeared $(10 \%)$ in solution $\left(\delta^{19} \mathrm{~F}=-115.5\right.$ and $\left.\delta^{31} \mathrm{P}=-81.0 \mathrm{ppm}\right)$ which presumably corresponds to another symmetrical isomer (Fig. 1c).

For compound 6 very similar spectra and their evolution were observed (ESI $\dagger$ ).

\section{Structure determination}

Chemical structure and assignment. A variety of NMR correlations allows one to prove the chemical structure of two main stereoisomers practically directly. For example, first, starting

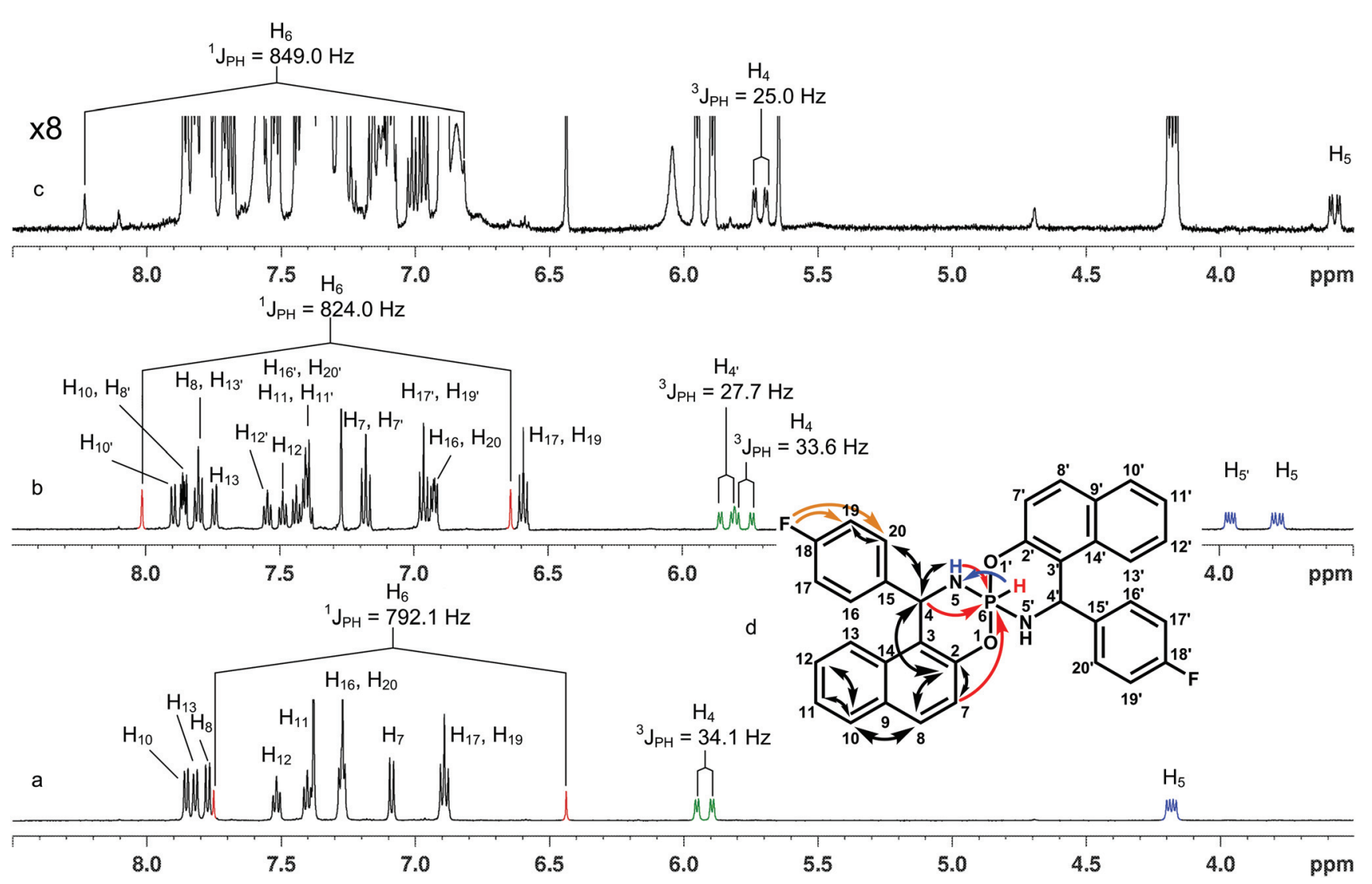

Fig. $1{ }^{1} \mathrm{H}$ spectra of 5 in $\mathrm{CDCl}_{3}$ at $303 \mathrm{~K}$. (a) Major product (fresh, 5a); (c) the same product after $24 \mathrm{~h}$; (b) second product; (d) structure of compound 5 a with principal NMR correlations: ${ }^{1} \mathrm{H}-{ }^{1} \mathrm{H}$ COSY and ${ }^{1} \mathrm{H}-{ }^{13} \mathrm{C}$ HMBC (black arrows), ${ }^{1} \mathrm{H}-{ }^{31} \mathrm{P}$ HMBC (red arrows), ${ }^{1} \mathrm{H}-{ }^{15} \mathrm{~N} \mathrm{HMBC}$ (blue arrows), ${ }^{19} \mathrm{~F}-{ }^{1} \mathrm{H}$ HETCOR (orange arrows). 
Table 1 Some experimental and calculated NMR parameters ${ }^{a}$ for compounds 4-6

\begin{tabular}{|c|c|c|c|c|c|c|c|c|c|c|c|c|}
\hline Comp. & $\mathrm{X}$ at $\mathrm{C}_{11}$ & $\mathrm{R}$ at $\mathrm{C}_{4}$ & Isomer & $\Delta E^{b}$ & $\delta^{31} \mathrm{P}$ & $\delta \mathrm{H}_{6}$ & $\delta \mathrm{H}_{16,20}$ & $\delta \mathrm{H}_{17,19}$ & $\delta \mathrm{H}_{4}$ & $\delta \mathrm{H}_{5}$ & ${ }^{1} J_{\mathrm{PH}}$ & ${ }^{3} \mathrm{JPH}_{\mathrm{PH}}$ \\
\hline \multirow[t]{6}{*}{4} & \multirow[t]{6}{*}{$\mathrm{H}$} & \multirow[t]{6}{*}{$\mathrm{Ph}$} & \multirow[t]{2}{*}{ I } & $\operatorname{Exp}^{c}(\mathbf{a})$ & -75.4 & 7.08 & 7.32 & 7.19 & 5.95 & 4.18 & 788.5 & 34.1 \\
\hline & & & & 0 & -75.2 & 7.66 & 7.64 & 7.41 & 5.98 & 3.77 & 715.4 & 36.1 \\
\hline & & & \multirow[t]{2}{*}{ II } & $\operatorname{Exp}(\mathbf{b})$ & -76.7 & 7.34 & $7.02,7.45$ & $6.93,7.29$ & $5.81,5.87$ & $3.80,4.00$ & 823.5 & $26.3,33.1$ \\
\hline & & & & 0.53 & -76.4 & 7.80 & $7.42,7.88$ & $7.21,7.58$ & $5.81,5.84$ & $3.46,3.83$ & 742.6 & $27.6,35.2$ \\
\hline & & & \multirow[t]{2}{*}{ III } & $\operatorname{Exp}(\mathbf{c})$ & -80.7 & 7.54 & $\mathrm{n} / \mathrm{d}^{d}$ & $\mathrm{n} / \mathrm{d}$ & 5.74 & 3.58 & 848.6 & 25.6 \\
\hline & & & & 1.33 & -82.5 & 7.75 & 7.87 & 7.58 & 5.65 & 3.36 & 762.7 & 25.2 \\
\hline \multirow[t]{6}{*}{5} & \multirow[t]{6}{*}{$\mathrm{H}$} & \multirow[t]{6}{*}{$\mathrm{FC}_{6} \mathrm{H}_{4}$} & \multirow[t]{2}{*}{ I } & $\operatorname{Exp}(\mathbf{a})$ & -75.2 & 7.09 & 7.26 & 6.88 & 5.91 & 4.17 & 792.1 & 34.1 \\
\hline & & & & 0 & -74.4 & 7.63 & 7.52 & 7.04 & 5.94 & 3.76 & 713.9 & 36.1 \\
\hline & & & \multirow[t]{2}{*}{ II } & $\operatorname{Exp}(\mathbf{b})$ & -76.6 & 7.32 & $6.91,7.39$ & $6.58,6.95$ & $5.76,5.82$ & $3.77,3.95$ & 824.0 & $27.7,33.6$ \\
\hline & & & & 0.47 & -75.7 & 7.75 & $7.37,7.82$ & $6.81,7.17$ & $5.77,5.86$ & $3.48,3.78$ & 738.3 & $27.6,34.6$ \\
\hline & & & \multirow[t]{2}{*}{ III } & $\operatorname{Exp}(\mathbf{a})$ & -80.5 & 7.52 & $\mathrm{n} / \mathrm{d}$ & $\mathrm{n} / \mathrm{d}$ & 5.70 & 3.56 & 849.0 & 25.0 \\
\hline & & & & 1.33 & -82.1 & 7.74 & 7.82 & 7.15 & 5.63 & 3.33 & 764.2 & 24.7 \\
\hline \multirow[t]{6}{*}{6} & \multirow[t]{6}{*}{$\mathrm{Br}$} & \multirow[t]{6}{*}{$\mathrm{Ph}$} & \multirow[t]{2}{*}{ I } & $\operatorname{Exp}(\mathbf{a})$ & -76.4 & 7.08 & 7.27 & 7.19 & 5.89 & 4.17 & 790.4 & 34.1 \\
\hline & & & & 0 & -75.6 & 7.62 & 7.58 & 7.41 & 5.92 & 3.74 & 718.3 & 36.0 \\
\hline & & & \multirow[t]{2}{*}{ II } & $\operatorname{Exp}(\mathbf{b})$ & -77.7 & 7.33 & $6.96,7.28$ & $6.96,7.28$ & $5.74,5.78$ & $3.77,3.95$ & 828.0 & $27.5,33.7$ \\
\hline & & & & 0.44 & -76.5 & 7.77 & $7.20,7.78$ & $7.18,7.59$ & $5.68,5.74$ & $3.34,3.81$ & 742.6 & $27.6,35.2$ \\
\hline & & & \multirow[t]{2}{*}{ III } & $\operatorname{Exp}(\mathbf{c})$ & -81.4 & 7.54 & $\mathrm{n} / \mathrm{d}$ & $\mathrm{n} / \mathrm{d}$ & 5.71 & 3.58 & 852.3 & 25.1 \\
\hline & & & & 0.67 & -80.5 & 7.69 & 7.78 & 7.59 & 5.60 & 3.25 & 769.9 & 24.1 \\
\hline
\end{tabular}

${ }^{a}$ Chemical shifts in ppm, spin-spin couplings in Hz. ${ }^{b}$ Relative energy, in kcal mol ${ }^{-1} \cdot{ }^{c}$ Experimental data. ${ }^{d}$ No data.

from ${ }^{1} \mathrm{H}-{ }^{15} \mathrm{~N}$ HSQC connectivities the $\mathrm{NH}$ protons were revealed, then the vicinal $\mathrm{H}_{4}$ protons were assigned based on COSY data. Next, the ${ }^{1} \mathrm{H}_{-}{ }^{31} \mathrm{P}$ HMBC connectivities from the $\mathrm{NH}$ and $\mathrm{H}_{4}$ to phosphorus allowed the determination of the structure of this central moiety (Fig. 1d). Further on, the ${ }^{1} \mathrm{H}-{ }^{13} \mathrm{C}$ HSQC/HMBC and ${ }^{1} \mathrm{H}-{ }^{1} \mathrm{H}$ COSY correlations allow establishing the structures of two aromatic fragments (ESI $\dagger$ ). In addition, for 5 the ${ }^{19} \mathrm{~F}-{ }^{1} \mathrm{H}$ HETCOR correlations help to establish connectivities up to fluorine atoms. As to the third (minor) isomer due to its low population and extensive overlapping with the signals of the first isomer in the ${ }^{1} \mathrm{H}$ NMR spectra, only some principal resonances can be identified with confidence (e.g. Fig. 1c). However, the $2 \mathrm{D}^{1} \mathrm{H}-{ }^{31} \mathrm{P}$ HMBC experiments (ESI $\dagger$ ) allow one to unambiguously reveal its signal in the ${ }^{31} \mathrm{P}$ spectra and also the $\mathrm{PH}, \mathrm{NH}$ and $\mathrm{H}_{4}$ proton resonances (e.g. for 5c Fig. 1c).

Isomeric structure. The analysis of the NMR parameters of diastereomers of the phosphoranes 4-6 reveals some general particularities - namely, there are notable differences in some CSs and spin-spin couplings (SSCs) of the isomers (ESI $\dagger$ ). The most spectacular are the values of direct ${ }^{1} J_{\mathrm{HP}}$ SSCs, that vary from $\sim 790$ (a-product) up to $\sim 850$ (c-product) $\mathrm{Hz}$ (Table 1), and also the difference in ${ }^{3} J_{\mathrm{PH} 4}$ SSCs. The ${ }^{1} \mathrm{H}$ CSs of $\mathrm{PH}$, $\mathrm{H}_{4}$ and aryl protons and ${ }^{31} \mathrm{P}$ CSs are diastereomer dependent in these products as well. Thus, it is likely that NMR parameters, being related to local magnetic environments, could be used in fine structural analysis.

In general, three chiral centers (at $\mathrm{P}, \mathrm{C}_{4}$ and $\mathrm{C}_{4^{\prime}}$ ) may generate four diastereomers: $\Delta_{\mathrm{P}} R_{\mathrm{c}} R_{\mathrm{c}} / \Lambda_{\mathrm{P}} S_{\mathrm{c}} S_{\mathrm{c}}, \Lambda_{\mathrm{P}} R_{\mathrm{c}} R_{\mathrm{c} \ddagger} / \Delta_{\mathrm{P}} S_{\mathrm{c}} S_{\mathrm{c}}, \Delta_{\mathrm{P}} R_{\mathrm{c}} S_{\mathrm{c}} /$ $\Lambda_{\mathrm{P}} S_{\mathrm{c}} R_{\mathrm{c}}$ and $\Delta_{\mathrm{p}} S_{\mathrm{c}} R_{\mathrm{c}} / \Lambda_{\mathrm{P}} R_{\mathrm{c}} S_{\mathrm{c}}$. However, when both aryls in chiral

\$The isomer III might be produced from isomer $\Delta_{\mathrm{p}} R_{\mathrm{c}} R_{\mathrm{c}}\left(\Lambda_{\mathrm{p}} S_{\mathrm{c}} S_{\mathrm{c}}\right)$ by the Berry pseudorotation process, so its configuration was assigned as $\Lambda_{\mathrm{p}} R_{\mathrm{c}} R_{\mathrm{c}}\left(\Delta_{\mathrm{P}} S_{\mathrm{c}} S_{\mathrm{c}}\right)$. centers are the same the last two isomers become equivalent in terms of NMR. Thus three main isomers were considered in details: with both aryl substituents being opposite to the $\mathrm{P}-\mathrm{H}$ bond $\left(\Delta_{\mathrm{P}} R_{\mathrm{c}} R_{\mathrm{c}} / \Lambda_{\mathrm{P}} S_{\mathrm{c}} S_{\mathrm{c}}, \mathbf{I}\right)$, with one aryl opposite to the $\mathrm{P}-\mathrm{H}$ bond and another one being on the same side of the cycle with the $\mathrm{P}-\mathrm{H}$ bond $\left(\Delta_{\mathrm{P}} R_{\mathrm{c}} S_{\mathrm{c}} / \Lambda_{\mathrm{P}} S_{\mathrm{c}} R_{\mathrm{c}}, \mathbf{I I}\right)$, in the third isomer both aryls are at the same side of the cycle with the $\mathrm{P}-\mathrm{H}$ bond $\left(\Lambda_{\mathrm{P}} R_{\mathrm{c}} R_{\mathrm{c}} / \Delta_{\mathrm{P}} S_{\mathrm{c}} S_{\mathrm{c}}\right.$, III) (Fig. 2).

Qualitative consideration of these structures predicts some stereospecific features. There are different dihedral angles between $\mathrm{H}_{4}-\mathrm{C}$ and $\mathrm{N}-\mathrm{P}$ in isomers I and III, that may lead to different three bond SSCs. As to the II-nd isomer, the geometries of its two spiro-halves are very similar to the halves of the I-st and III-rd isomers, therefore two sets of signals are expected for its ${ }^{1} \mathrm{H}\left({ }^{13} \mathrm{C},{ }^{19} \mathrm{~F}\right)$ spectra.

Thus, preliminary identification can be based on NOEs and symmetry considerations. Presumably, the "a" (major) products can be ascribed to the $\mathbf{I}$ isomer because there is no NOE between the ortho-aryl and $\mathrm{P}-\mathrm{H}$ protons. Lack of symmetry in the second product ("b") may be indicative of the II-isomer. As to the co-product ("c") that appeared after some time in solution of the major isomer ("a"), there are no clear NOEs that can be used due to its low population and the signal overlapping with the main product.

To develop a well-argued relationship between the NMR parameters and the fine isomeric structure, DFT calculations of the NMR parameters were carried out for these structural hypotheses. It is well demonstrated that modern GIAO CS calculations on ${ }^{13} \mathrm{C},{ }^{15} \mathrm{~N}$ and ${ }^{1} \mathrm{H}$ nuclei achieved experimental accuracy and can be used as an additional tool for chemical structure elucidation. There are a number of examples of application of such calculations on these nuclei to obtain fine information on the isomeric, tautomeric and conformational structure. ${ }^{39-53,57-60}$ At the same time the examples of 


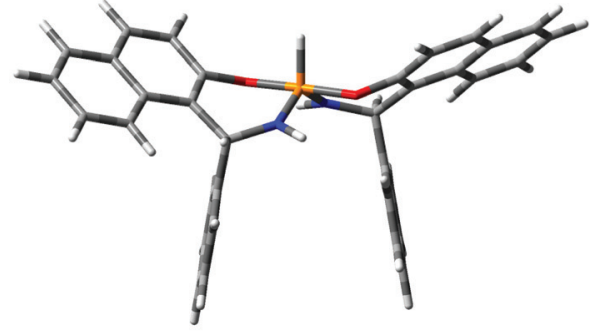

I

$\left(\Delta_{\mathrm{p}} R_{\mathrm{c}} R_{\mathrm{c}}\right)$

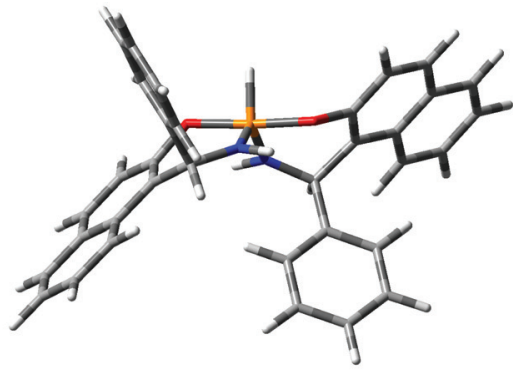

II

$\left(\Delta_{\mathrm{p}} R_{\mathrm{c}} S_{\mathrm{c}}\right)$

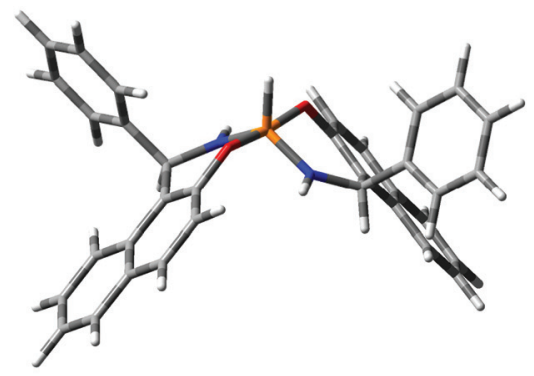

III

$\left(\Lambda_{\mathrm{p}} R_{\mathrm{c}} R_{\mathrm{c}}\right)$

Fig. 2 Energy minimized structures of the main isomers of the title spirophosphorane 4.

application of these approaches on phosphorus are rather sparse. $^{54-56}$

We used a combination (PBE1PBE/6-311G(2d,2p)//PBE1PBE/ $6-31+G(d))$ that proved to be reliable and effective for ${ }^{31} \mathrm{P}$ NMR CS calculations. First, the geometry optimization in the frames of the DFT (PBE1PBE/6-31+G(d)) method predicts that these three main isomers are close in energy (Table 1). Additional calculations with the inclusion of solvent effects (in the frames of the PCM model, Table S1†) do not change notably the energy distribution. In general, these results are in qualitative agreement with experimental findings that all three isomers are present in the reaction mixture after some time.

The results of the CS and SSC calculations (GIAO PBE1PBE/ 6-311G(2d,2p)) for optimized structures are also in agreement with preliminary conclusions (some essential data are summarized in Table 1). According to the calculations, the $\mathrm{PH}$, $\mathrm{H}_{4}$ and $\mathrm{NH}$ protons and ${ }^{31} \mathrm{P}$ CSs should be notably different, particularly, for the I-st and the III-rd isomers. Namely, for the I-isomer the $\mathrm{PH}$ proton should resonate at a higher field than for the III-isomer, while for the $\mathrm{H}_{4}$ and the $\mathrm{NH}$ protons the reverse should be observed. Likewise the ${ }^{31} \mathrm{P}$ resonance signal of the I-isomer should be at a lower field than in the III-isomer. For the II-isomer, intermediate values are expected (Table 1). Thus, according to the CS data the major ("a") product should be assigned to the I-isomer for all title compounds. The second non-symmetrical product corresponds to the II-diastereomer while the minor product may be assigned to the III-isomer.

Some SSCs also demonstrate spectacular distinctions for three isomers (Table 1) that correlate well with experimental data. As can be seen the ${ }^{1} J_{\mathrm{HP}}$ constants are characteristic of these isomers and can be used to assign the isomeric structure. The smallest values $(715.4 \mathrm{~Hz})$ are predicted for the I-st isomers while for the III-rd forms these values are notably larger $(762.7 \mathrm{~Hz})$. For the II-isomers the $\mathrm{PH}$ direct SSCs are expected to have intermediate values $(742.6 \mathrm{~Hz})$. The calculations slightly underestimate (by $c a$. 1.1) the experimental data although the correlation is quite good. Thus, the comparison of the calculated versus experimental SSCs allows the assignment of the major product to the I-st isomer, the second product to the II-nd isomer and the least populated product to the III-rd isomer.

The ${ }^{3} J_{\mathrm{HP}}$ between $\mathrm{P}$ and $\mathrm{H}_{4}$ is also very stereospecific (Table 1). First, the calculations predict SSCs to have large absolute values and be essentially different, at least, for the I-st and III-rd isomers. For the II-nd isomers there are two different values for each half but these SSC are close to the corresponding SSCs of the I-st and III-rd isomers, respectively. In spite of the fact that theory slightly underestimates these SSCs, the calculated values and tendencies are in good agreement with the experimentally observed data (Table 1). Thus, the comparison of the experimental versus calculated data also allows the assignment that is in accordance with the above conclusion.

These conclusions were supported by solid-state data in some cases. Namely, good crystals suitable for X-ray analysis were grown for the second isomer of racemic $\mathbf{4}$, which is crystallized as a conglomerate, and for the major product of racemic 5. The results of X-ray single crystal diffraction turned out to be in full agreement with the NMR data. In crystals the major product of $\mathbf{5}$ is realized in the I form (see Fig. 3) with both aryls directed opposite to the $\mathrm{P}-\mathrm{H}$ bond. In general, the solid-state geometry is close to the DFT optimized one.

It is interesting that the crystallized product of $\mathbf{4}$ corresponded to the asymmetrical II-form that is also in agreement with the conclusion based on the NMR data. Thus for the title chiral pentacoordinate spirophosphoranes there are several NMR parameters that can be used to establish the isomeric structure. These relationships are summarized in Fig. 4.

Correlation of NMR parameters with the isomeric structure for other chiral pentacoordinate spirophosphoranes

The interplay of the NMR experiment and theory can be safely used to determine the isomeric structure of chiral pentacoordinate spirophosphoranes with six-membered heterocycles. To this end it is of interest to see if this approach could also be applied to determine the isomeric structure of other similar chiral pentacoordinate spirophosphoranes, e.g. with five-membered heterocycles. For example, there are experimental data for a series of chiral pentacoordinate spirophosphoranes obtained from $\alpha$-amino carbonic acids (Scheme 2). ${ }^{33-37}$ These 

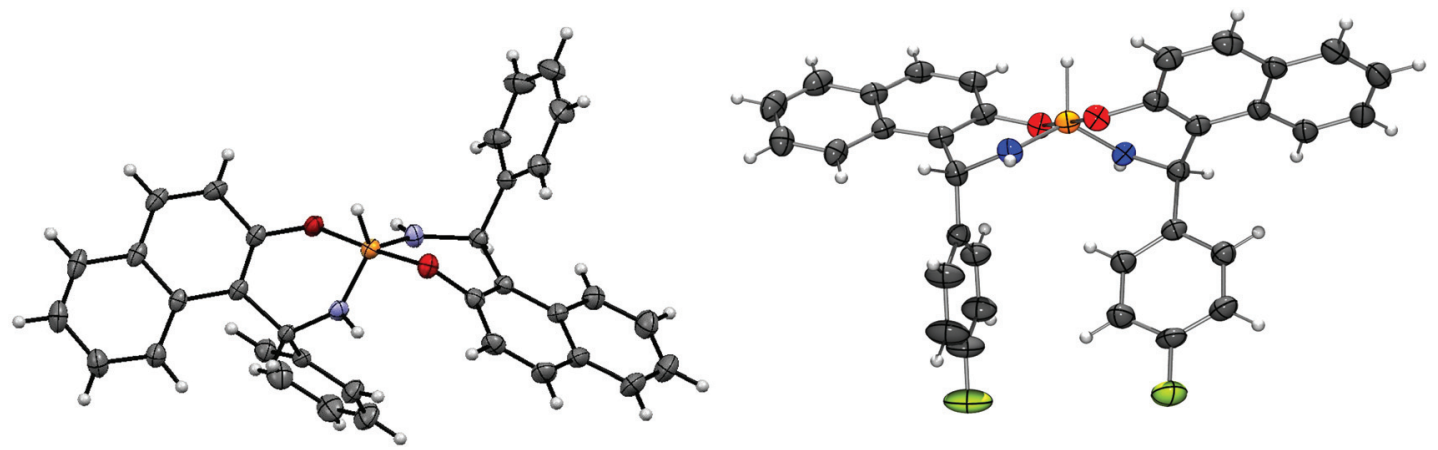

Fig. 3 Molecular geometry of diastereomers $4 b$ (left) and $5 a$ (right) as determined from X-ray single crystal diffraction.

\begin{tabular}{|ccccc|}
\hline$\delta^{31} \mathrm{P}$ & $>$ & $\delta^{31} \mathrm{P}$ & $>$ & $\delta^{31} \mathrm{P}$ \\
\hline${ }^{1} J_{\mathrm{PH}}$ & $<$ & ${ }^{1} J_{\mathrm{PH}}$ & $<$ & ${ }^{1} J_{\mathrm{PH}}$ \\
\hline${ }^{3} J_{\mathrm{PH}}$ & $>$ & ${ }^{3} J_{\mathrm{PH}}$ & $>$ & ${ }^{3} J_{\mathrm{PH}}$ \\
\hline
\end{tabular}

Fig. 4 Schematic representation of three isomers of 4-6 and the main relationships between the NMR parameters and isomeric structure. Magnetically equivalent fragments are colored identically.

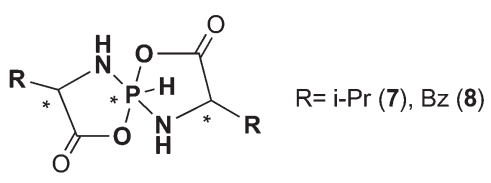

Scheme 2

compounds were extensively analyzed by CD and X-ray single diffraction. When enantiomerically pure reagents were being used, the reactions produced only two diastereomers.

A brief survey of available NMR data demonstrates that there are also some specific features of experimental CSs and SSCs characteristic of two diastereomers although somewhat distinct from those observed for the title compounds. First, for five-membered spirophosphoranes the reverse ${ }^{31} \mathrm{P}$ CS distribution is observed, i.e. the "I" isomers resonate at a higher field than "III" isomers (some data are included in Table 2).§ Second, the ${ }^{1} J_{\mathrm{PH}}$ values are smaller for the "I" isomers than for the "III"-forms. As to the ${ }^{3} J_{\mathrm{PH}}$ constants they are notably smaller $(<13 \mathrm{~Hz})$. Third, there are substantial long range ${ }^{4} J_{\underline{\mathrm{HPH}} 4}$

$\S$ Unfortunately, ${ }^{1} \mathrm{H}$ CS's data cannot be analyzed in this case as different solvents were used in experiments for different diastereomers.
SSCs $(2.4 \mathrm{~Hz})$ in the "III" forms that were not seen in the "I" isomers presumably due to their small values.

These differences are reproduced by theory. According to our calculations performed for the simplest compounds from this series with i-Pr (7) or $\mathrm{Bz}$ (8) groups at chiral carbons (Table 2), indeed, the "I" isomer has to resonate at a higher field in the ${ }^{31} \mathrm{P}$ NMR spectra than the "III" form.

The calculated SSCs are also qualitatively consistent with the experimental values, although some underestimation is also seen. First, a larger one bond SSC is predicted for the "III" isomers (Table 2) than for the "I" form. According to the calculations, the ${ }^{3} J_{\mathrm{PH}}$ SSCs should be notably smaller than for the title compounds. Moreover, for the "III"-isomers one may expect a long range four bond SSC between HP and $\mathrm{H}_{4}$ ( 2.0 versus $0.5 \mathrm{~Hz}$ ) larger than for the "I" isomer. Thus, several NMR parameters can also be used to determine the relative configuration at chiral carbons in these pentacoordinate spirophosphoranes.

\section{Discussion}

Let us consider why some relationships are different in these two series of spirophosphoranes. There are two essential NMR features that distinguish 5-membered spirophosphoranes from 6-membered compounds: (a) ${ }^{3} J_{\mathrm{PH}}$ - small absolute value for the 5-cycle and large for the 6-cycle; (b) $\delta{ }^{31} \mathrm{P}_{\mathbf{I}}>\delta^{31} \mathrm{P}_{\mathrm{III}}$ for 6-membered and $\delta^{31} \mathrm{P}_{\mathbf{I}}<\delta^{31} \mathrm{P}_{\text {III }}$ for 5-membered.

To reveal key factors that determine these differences we analyzed the influence of substituents at carbon chiral centers and the nature of the fused aromatic fragments theoretically. To simplify the task and to exclude the specific influence of fused aromatic fragments, the models with the benzo fragment instead of the naphthyl group were analyzed (Fig. 5a and $\mathrm{b}$, Table 3). According to these calculations, the relationships between the NMR parameters and isomeric structure are expected to be essentially similar to the title compounds. Thus, there is no specific effect of the naphthyl moiety on the NMR parameters' distribution in these isomers.

The next step to simplify the model is to check whether there is a specific influence of substituents at chiral carbons (e.g. steric interactions). For this purpose we analyzed models 
Table 2 Some experimental and calculated NMR parameters ${ }^{a}$ for compounds 7 and 8

\begin{tabular}{|c|c|c|c|c|c|c|c|c|c|c|}
\hline Comp. & $\mathrm{R}$ at $\mathrm{C}_{4}$ & Isomer & $\Delta E^{b}$ & $\delta^{31} \mathrm{P}$ & $\delta \mathrm{H}_{6}$ & $\delta \mathrm{H}_{4}$ & $\delta \mathrm{H}_{5}$ & ${ }^{1} J_{\mathrm{PH}}$ & ${ }^{3} J_{\mathrm{PH} 4}$ & ${ }^{4} \mathrm{JH}_{\mathrm{H} 6 \mathrm{H} 4}$ \\
\hline \multirow[t]{4}{*}{7} & \multirow[t]{4}{*}{ i-Pr } & \multirow[t]{2}{*}{$\mathbf{I}$} & $\operatorname{Exp}^{c}(\mathbf{a})^{37}$ & -65.0 & 7.18 & 3.71 & 5.76 & 798.5 & 13.0 & $\mathrm{n} / \mathrm{d}^{d}$ \\
\hline & & & 0.19 & -65.6 & 7.82 & 3.73 & 2.82 & 697.2 & 8.8 & 0.5 \\
\hline & & \multirow[t]{2}{*}{ III } & $\operatorname{Exp}(\mathbf{b})^{37}$ & -63.7 & 7.43 & 3.80 & 3.47 & 824.4 & $\mathrm{n} / \mathrm{d}$ & 2.4 \\
\hline & & & 0 & -62.1 & 7.79 & 3.70 & 2.84 & 724.0 & 5.9 & 2.0 \\
\hline \multirow[t]{4}{*}{8} & \multirow[t]{4}{*}{$\mathrm{Bz}$} & \multirow[t]{2}{*}{ I } & $\operatorname{Exp}(\mathbf{a})^{36}$ & -63.0 & 7.09 & $\mathrm{n} / \mathrm{d}$ & $\mathrm{n} / \mathrm{d}$ & 804.9 & $\mathrm{n} / \mathrm{d}$ & $\mathrm{n} / \mathrm{d}$ \\
\hline & & & 0 & -68.5 & 7.95 & 4.16 & 3.02 & 710.3 & 10.8 & 0.4 \\
\hline & & \multirow[t]{2}{*}{ III } & $\operatorname{Exp}(\mathbf{b})^{36}$ & -60.0 & 5.64 & $\mathrm{n} / \mathrm{d}$ & $\mathrm{n} / \mathrm{d}$ & 810.2 & $\mathrm{n} / \mathrm{d}$ & 2.4 \\
\hline & & & 3.58 & -64.5 & 6.62 & 3.81 & 2.67 & 733.6 & 9.4 & 2.1 \\
\hline
\end{tabular}

${ }^{a}$ Chemical shifts in ppm, spin-spin couplings in Hz. ${ }^{b}$ Relative energy, in kcal mol ${ }^{-1} \cdot{ }^{c}$ Experimental data. ${ }^{d}$ No data.

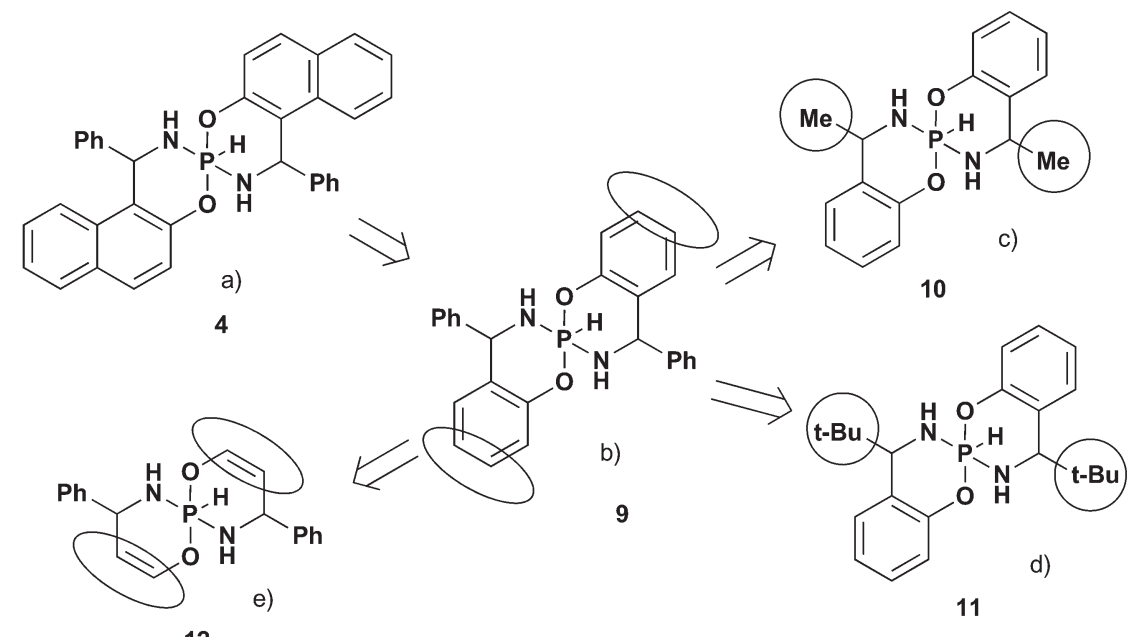

Fig. 5 Step-by-step simplification of the title pentacoordinate spirophosphoranes.

Table 3 Calculated ${ }^{a}$ NMR parameters for models 9-12

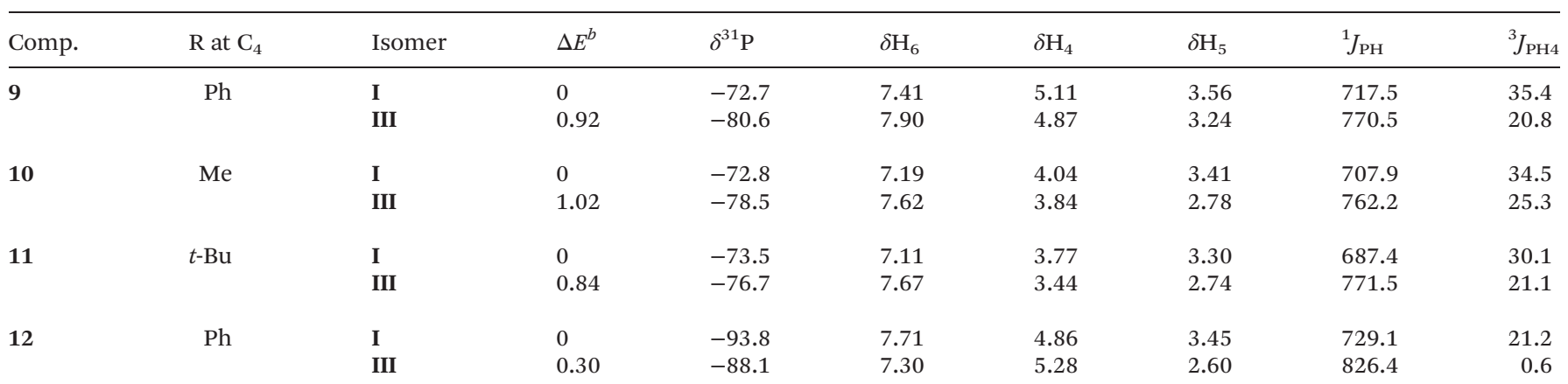

${ }^{a}$ Chemical shifts in ppm, spin-spin couplings in Hz. ${ }^{b}$ Relative energy, in kcal mol ${ }^{-1}$.

with small (Me, 10) and large ( $t$-Bu, 11) alkyl groups, as well as aromatic (Ph, 9) fragments at chiral centers (Fig. 5c and d). According to calculations (Table 3 ), the main tendencies are also the same as for the title compounds. That is there is no specific influence of the $\mathrm{R}$ at the chiral carbon atoms on the $\delta^{31} \mathrm{P}$ and ${ }^{3} J_{\mathrm{PH}}$ difference in the main isomers.
In order to reveal the impact of the fused aromatic unit on NMR parameters, the benzo fragment was replaced by a double bond (12, Fig. 4e) in the next step. In this case the reverse distribution of ${ }^{31} \mathrm{P}$ CSs for the two main isomers and notably smaller ${ }^{3} J_{\mathrm{PH}}$ SSCs are expected. This is very similar to the trends found in 5-membered compounds. 

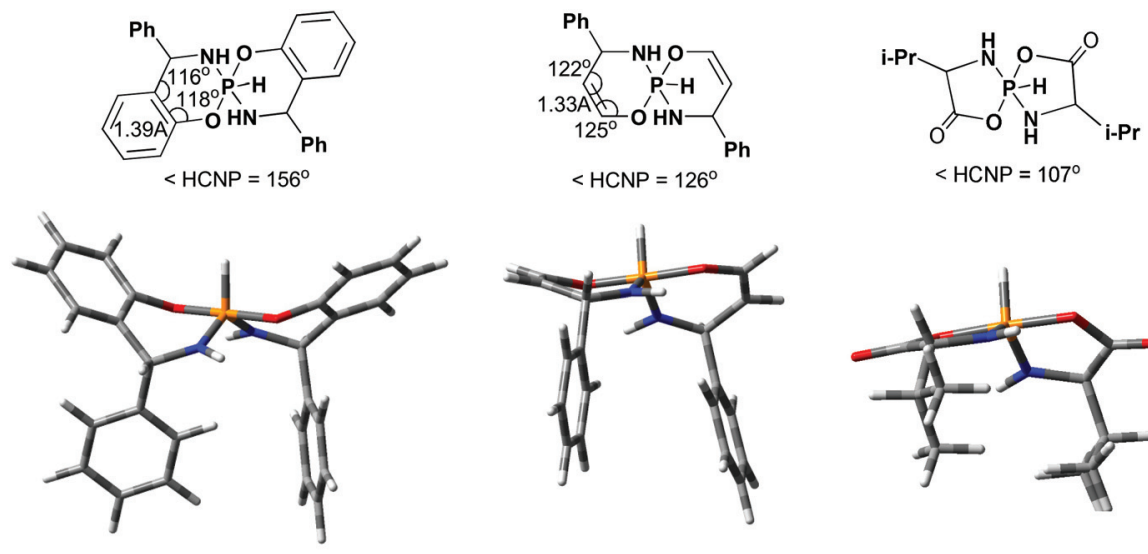

9 I

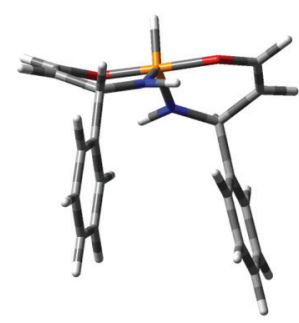

121

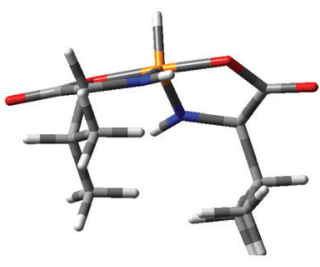

7 I

Fig. 6 Some geometrical parameters and calculated 3D structures for different 5- and 6-membered pentacoordinate spirophosphoranes.

Thus, in both series the nature of the substituent at the chiral center is not principal. The nature of the fused aromatic fragment is also not crucial. But NMR parameters are considerably different for compounds with the aromatic system and those without the aromatic system. In this case, it is the geometry of the heterocycle which plays the crucial role: while in 6-membered spirophosphoranes with the fused aromatic system the heterocycle adopts boat conformation, in 5- and 6-membered compounds without the aromatic fragment the heterocycle is essentially flat (or envelope) (Fig. 6). Therefore, in the first case the $\mathrm{H}_{4}-\mathrm{C}_{4}-\mathrm{N}-\mathrm{P}$ dihedral angle is about $156^{\circ}$ and results in a large ${ }^{3} J_{\mathrm{PH}}$ value, in the latter cases these angles are $c a .126^{\circ}$ and $107^{\circ}$, thus small ${ }^{3} J_{\mathrm{PH}}$ should be observed. The same difference in the conformation leads to a different distribution of ${ }^{31} \mathrm{P}$ CSs in the two main isomers.

\section{Conclusions}

The major product of the Betti based derivatives corresponds to the isomers with both substituents at chiral carbons being opposite to the $\mathrm{P}-\mathrm{H}$ proton. The next populated product corresponds to the isomer with different chiralities at carbons. The least populated isomer is one with both substituents being at the same side of the heterocycle as the $\mathrm{P}-\mathrm{H}$ bond.

For such pentacoordinate chiral spirophosphoranes bearing two six-membered rings at the phosphorus atom the distinct NMR features, which allow establishing the isomeric structure, can be formulated as follows: the $\Delta_{\mathrm{P}} R_{\mathrm{c}} S_{\mathrm{c}} / \Lambda_{\mathrm{P}} R_{\mathrm{c}} S_{\mathrm{c}}$ isomer has two nonequivalent sets of signals in ${ }^{1} \mathrm{H}\left({ }^{13} \mathrm{C}\right) \mathrm{NMR}$; the $\Delta_{\mathrm{P}} R_{\mathrm{c}} R_{\mathrm{c}} / \Lambda_{\mathrm{P}} S_{\mathrm{c}} S_{\mathrm{c}}$ isomer resonances at a lower field in ${ }^{31} \mathrm{P}$ $\mathrm{NMR}$, the $\mathrm{PH}$ proton resonances at a higher field, ${ }^{1} J_{\mathrm{PH}}$ is smaller, ${ }^{3} J_{\mathrm{PH}}$ is larger than similar parameters for the $\Delta_{\mathrm{P}} S_{\mathrm{c}} S_{\mathrm{c}} /$ $\Lambda_{\mathrm{P}} R_{\mathrm{c}} R_{\mathrm{c}}$ isomer.

For similar spirophosphoranes bearing two five-membered rings at the phosphorus atom the NMR indicators are slightly different, in full agreement with the theory.
This study shows that the interplay of NMR experiments and DFT calculations of NMR parameters is a powerful and reliable method for determining the relative configurations of the pentacoordinate $\mathrm{P}-\mathrm{H}$-spirophosphoranes in solution.

\section{Experimental section}

\section{NMR spectroscopy}

All NMR experiments were performed with 600, 500 and $400 \mathrm{MHz}$ (600.1, 500.1 and $400.1 \mathrm{MHz}$ for ${ }^{1} \mathrm{H}$ NMR; 150.9, 125.8 and $100.6 \mathrm{MHz}$ for ${ }^{13} \mathrm{C} \mathrm{NMR} ; 242.9,202.5$ and 162.0 MHz for ${ }^{31} \mathrm{P}$ NMR, 60.81 MHz for ${ }^{15} \mathrm{~N}$ NMR, 376.5 for ${ }^{19} \mathrm{~F}$ respectively) spectrometers equipped with a $5 \mathrm{~mm}$ diameter probehead and a pulsed gradient unit capable of producing magnetic field pulse gradients in the $z$-direction of 53.5 $\mathrm{G} \mathrm{cm}^{-1}$. For ${ }^{1} \mathrm{H}-{ }^{13} \mathrm{C}$ correlations the HSQC experiment is optimized for $J=145 \mathrm{~Hz}$. For ${ }^{1} \mathrm{H}-{ }^{13} \mathrm{C}$ long range correlations the HMBC experiment is optimized for $J=8 \mathrm{~Hz}$. For ${ }^{1} \mathrm{H}^{3}{ }^{31} \mathrm{P}$ long range correlations the $\mathrm{HMBC}$ experiment is optimized for $J=$ $8 \mathrm{~Hz}$. For ${ }^{1} \mathrm{H}^{-15} \mathrm{~N}$ correlations the HSQC experiment is optimized for $J=90 \mathrm{~Hz}$. For ${ }^{1} \mathrm{H}^{-15} \mathrm{~N}$ long range correlations the HMBC experiment is optimized for $J=6 \mathrm{~Hz}$. For ${ }^{19} \mathrm{~F}^{1}{ }^{1} \mathrm{H}$ long range correlations the HETCOR experiment is optimized for $J=$ $3 \mathrm{~Hz}$. DOSY experiments were performed with ledbpgp2s, using a stimulated echo sequence and two spoil gradients. NOE experiments were performed with 1D DPFGNOE techniques. CSs ( $\delta$ in ppm) were referenced to the solvent $\mathrm{CDCl}_{3}$ $\left(\delta=7.27 \mathrm{ppm}\right.$ for ${ }^{1} \mathrm{H}$ and $77.0 \mathrm{ppm}$ for $\left.{ }^{13} \mathrm{C} \mathrm{NMR}\right)$ and to external $\mathrm{H}_{3} \mathrm{PO}_{4}(0.0 \mathrm{ppm})$ for ${ }^{31} \mathrm{P}$ NMR spectra, to external $\mathrm{CH}_{3} \mathrm{CN}$ (235.5 ppm) for ${ }^{15} \mathrm{~N}$ NMR spectra, to external $\mathrm{C}_{6} \mathrm{~F}_{6}$ $(-164.9 \mathrm{ppm})$ for ${ }^{19} \mathrm{~F}$ NMR spectra.

\section{Calculations}

The quantum chemical calculations were performed using the Gaussian 03 software package. ${ }^{61}$ Full geometry optimizations have been carried out within the framework of the DFT (PBE1PBE) method using 6-31+G(d) basis sets. ${ }^{31} \mathrm{P}$ CSs were 
calculated at the PBE1PBE/6-311G(2d,2p) level of theory. ${ }^{56}$ ${ }^{31} \mathrm{P}$ CSs were referred to $\mathrm{H}_{3} \mathrm{PO}_{4}$ calculated at the same level of theory. The linear scaling procedure was applied. ${ }^{56}{ }^{1} \mathrm{H}$ CSs were referred to TMS.

\section{Synthesis of 1-( $\alpha$-aminobenzyl)-2-naphthols (1-3)}

Compounds 1-3 were synthesized in several steps. First, the corresponding 1,3-diaryl-2,3-dihydro-1H-naphth[1,2-e][1,3] oxazines were obtained. ${ }^{62-64}$ which were then hydrolyzed by trifluoroacetic acid in the presence of water. ${ }^{65}$ The free bases were isolated by treating the resulting trifluoroacetates with sodium carbonate. ${ }^{66}$

\section{Synthesis of P-H-spirophosphoranes (4-6)}

Spirophosphoranes (4-6) were synthesized by the reaction of the Betti bases and hexaethyltriamidophosphite: (1) without the addition of the catalyst (method A, only 4) resulting in the predominant formation of the $\left(\Delta_{\mathrm{P}} R_{\mathrm{c}} R_{\mathrm{c}} / \Delta_{\mathrm{P}} S_{\mathrm{c}} S_{\mathrm{c}}\right)$-isomer; (2) with the addition of diethylamine hydrochloride (5 mol\%) as the catalyst (method $\mathrm{B})$, which allows obtaining $\left(\Delta_{\mathrm{P}} R_{\mathrm{c}} R_{\mathrm{c}} / \Delta_{\mathrm{P}} S_{\mathrm{c}} S_{\mathrm{c}}\right)$ and $\left(\Delta_{\mathrm{p}} R_{\mathrm{c}} S_{\mathrm{c}} / \Delta_{\mathrm{P}} S_{\mathrm{c}} R_{\mathrm{c}} \equiv \Delta_{\mathrm{P}} S_{\mathrm{c}} R_{\mathrm{c}} / \Delta_{\mathrm{P}} R_{\mathrm{c}} S_{\mathrm{c}}\right)$-isomers in a ratio close to $1: 1$ by influencing the rate of $\mathrm{P}-\mathrm{Z}$ bond cleavage $(\mathrm{Z}=\mathrm{O}, \mathrm{N}) \cdot{ }^{67}$

Method A: 1-( $\alpha$-Aminobenzyl)-2-naphthol (1) (4 mmol) was dissolved in dry benzene $(12 \mathrm{~mL})$ under heating. Then the solution of hexaethyltriamidophosphite $(2 \mathrm{mmol})$ in dry benzene $(3 \mathrm{~mL})$ was added and the reaction mixture was kept at reflux under argon for 8 hours. After that the solvent was removed and the residue was analyzed by ${ }^{1} \mathrm{H}$ and ${ }^{31} \mathrm{P}$ NMR spectroscopy for the diastereomers' (4a and $\mathbf{4 b}$ ) ratio determination $\left(\left(\Delta_{\mathrm{P}} R_{\mathrm{c}} R_{\mathrm{c}} / \Lambda_{\mathrm{P}} S_{\mathrm{c}} S_{\mathrm{c}}\right):\left(\Delta_{\mathrm{p}} R_{\mathrm{c}} S_{\mathrm{c}} / \Lambda_{\mathrm{P}} S_{\mathrm{c}} R_{\mathrm{c}}\right)=65: 35\right)$. Pure $\left(\Delta_{\mathrm{p}} R_{\mathrm{c}} R_{\mathrm{c}} /\right.$ $\Lambda_{\mathrm{P}} S_{\mathrm{c}} S_{\mathrm{c}}$ )-P-H-phosphorane (4a) was obtained by recrystallization from benzene.

Method B: 1-( $\alpha$-Aminobenzyl)-2-naphthols (1-3) (4 mmol) were dissolved in dry benzene $(12 \mathrm{~mL})$ under heating. Then dry diethylamine hydrochloride (0.1 mmol, $5 \mathrm{~mol} \%)$ was added followed by the addition of hexaethyltriamidophosphite solution $(2 \mathrm{mmol})$ in dry benzene $(3 \mathrm{~mL})$. The resulting reaction mixture was kept at reflux under argon for 5 hours. After that the solvent was removed and the residue was analyzed by ${ }^{1} \mathrm{H}$ and ${ }^{31} \mathrm{P}$ NMR spectroscopy for the diastereomers' (a and $\mathbf{b}$ ) ratio determination $\left(\left(\Delta_{\mathrm{P}} R_{\mathrm{c}} R_{\mathrm{c}} / \Lambda_{\mathrm{P}} S_{\mathrm{c}} S_{\mathrm{c}}\right):\left(\Delta_{\mathrm{P}} R_{\mathrm{c}} S_{\mathrm{c}} / \Lambda_{\mathrm{P}} S_{\mathrm{c}} R_{\mathrm{c}}\right)=1: 1.1\right.$ for 4, 1:1 for 5, 1:0.9 for 6). Pure $\left(\Delta_{\mathrm{P}} R_{\mathrm{c}} R_{\mathrm{c}} / \Lambda_{\mathrm{P}} S_{\mathrm{c}} S_{\mathrm{c}}\right)-\mathbf{4 a}-\mathbf{6 a}$ and

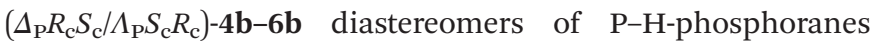
were obtained by fractional crystallization from benzene.

\section{Physical data}

1-[Amino-(4-fluorophenyl)methyl]-2-naphthol trifluoroacetate (2. $\left.\mathrm{CF}_{3} \mathbf{C O O H}\right)$. Yield: $82.2 \%$; m.p. $150-151{ }^{\circ} \mathrm{C} . \delta_{\mathrm{H}}(400.1 \mathrm{MHz}$; DMSO-d 6 ; TMS) 6.30 (1 H, s, PhCHN), 7.19-8.06 (10 H, m, Ph), $8.80\left(3 \mathrm{H}, \mathrm{br}, \mathrm{NH}_{3}{ }^{+}\right)$. IR (KBr): $\nu=1516\left(\mathrm{COO}^{-}\right), 1586,1601$ $\left(\mathrm{C}=\mathrm{C}_{\text {naphth }}\right), 1665\left(\mathrm{COO}^{-}\right), 3066,3288 \mathrm{~cm}^{-1}\left(\mathrm{NH}_{3}^{+}\right)$; elemental analysis calcd (\%) for $\mathrm{C}_{19} \mathrm{H}_{15} \mathrm{~F}_{4} \mathrm{NO}_{3}$ : C59.85, H3.96, N 3.67; found: C 59.68, H 3.77, N 3.55.

1-( $\alpha$-Aminobenzyl)-6-bromo-2-naphthol trifluoroacetate (3.CF $\mathbf{C F O O H}_{3}$. Yield: $84.0 \%$; m.p. $162-164{ }^{\circ} \mathrm{C} . \delta_{\mathrm{H}}(400.1 \mathrm{MHz}$; DMSO-d $_{6}$; TMS) 6.29 (1 H, s, PhCHN), 7.30-8.16 (10 H, m, Ph), $8.79\left(3 \mathrm{H}, \mathrm{br}, \mathrm{NH}_{3}^{+}\right)$. IR (KBr): $\nu=1503\left(\mathrm{COO}^{-}\right), 1582,1598$ $\left(\mathrm{C}=\mathrm{C}_{\text {naphth }}\right), 1664\left(\mathrm{COO}^{-}\right), 3066,3254 \mathrm{~cm}^{-1}\left(\mathrm{NH}_{3}^{+}\right)$; elemental analysis calcd (\%) for $\mathrm{C}_{19} \mathrm{H}_{15} \mathrm{BrF}_{3} \mathrm{NO}_{3}$ : C51.60, H3.42, $\mathrm{Br}$ 18.07, N 3.17; found: C 51.78, H 3.57, Br 17.89, N 3.35.

1-( $\alpha$-Aminobenzyl)-6-bromo-2-naphthol (3). Yield: 95.9\%; m.p. $137-138{ }^{\circ} \mathrm{C} . \delta_{\mathrm{H}}\left(500.1 \mathrm{MHz} ; \mathrm{CDCl}_{3}\right.$; TMS $) 6.13(1 \mathrm{H}, \mathrm{s}$, PhCHN), 7.19-7.89 (10 H, m, Ph). IR (KBr): $\nu=1589,1613$ $\left(\mathrm{C}=\mathrm{C}_{\text {naphth }}\right), 3292,3362 \mathrm{~cm}^{-1}\left(\mathrm{NH}_{2}\right)$; elemental analysis calcd (\%) for $\mathrm{C}_{17} \mathrm{H}_{14} \mathrm{BrNO}$ : C62.21, $\mathrm{H} 4.30, \mathrm{Br}$ 24.35, $\mathrm{N}$ 4.27; found: C62.04, H4.47, Br 24.16, N4.35.

$\left(\Delta_{\mathrm{p}} R_{\mathrm{c}} R_{\mathrm{c}} / \Lambda_{\mathrm{P}} S_{\mathrm{c}} S_{\mathrm{c}}\right)$-6a-Hydro-5,14-diphenyldinaphtho[2,1- $\left.b, 2,1-h\right]$ 1,7,5,11,6-dioxadiazaphosphaspiro[5.5] undecadiene-7a,16a (4a). (0.54 g, 51.6\%, method A); (0.28 g, 26.5\%, method B); m.p. $180-182{ }^{\circ} \mathrm{C} . \delta_{\mathrm{H}}\left(600.1 \mathrm{MHz} ; \mathrm{CDCl}_{3}\right.$; TMS $) 7.86(2 \mathrm{H}, \mathrm{d}$, $\left.{ }^{3} J_{\mathrm{HH}} 8.7, \mathrm{H}_{10}, \mathrm{H}_{10^{\prime}}\right), 7.83\left(2 \mathrm{H}, \mathrm{d},{ }^{3} J_{\mathrm{HH}} 8.7, \mathrm{H}_{12}, \mathrm{H}_{12^{\prime}}\right), 7.74(2 \mathrm{H}$, $\left.\mathrm{d},{ }^{3} J_{\mathrm{HH}} 8.8, \mathrm{H}_{8}, \mathrm{H}_{8^{\prime}}\right), 7.49\left(2 \mathrm{H}, \mathrm{dd},{ }^{3} J_{\mathrm{HH}} 8.7,{ }^{3} J_{\mathrm{HH}} 7.5, \mathrm{H}_{13}, \mathrm{H}_{13^{\prime}}\right)$, $7.37\left(2 \mathrm{H}, \mathrm{dd},{ }^{3} J_{\mathrm{HH}} 8.7,{ }^{3} J_{\mathrm{HH}} 7.5, \mathrm{H}_{11}, \mathrm{H}_{11^{\prime}}\right), 7.32(4 \mathrm{H}, \mathrm{dd}$, $\left.{ }^{3} J_{\mathrm{HH}} 8.7,{ }^{3} J_{\mathrm{HH}} 7.3,{ }^{4} J_{\mathrm{HH}} 1.8, \mathrm{H}_{16}, \mathrm{H}_{16}, \mathrm{H}_{20}, \mathrm{H}_{20^{\prime}}\right), 7.19(6 \mathrm{H}, \mathrm{m}$, $\left.\mathrm{H}_{17}-\mathrm{H}_{19}, \mathrm{H}_{17^{\prime}}-\mathrm{H}_{19^{\prime}}\right), 7.08\left(1 \mathrm{H}, \mathrm{d},{ }^{1} J_{\mathrm{PH}} 788.5, \mathrm{H}_{6}\right), 7.07(2 \mathrm{H}, \mathrm{d}$, $\left.{ }^{3} J_{\mathrm{HH}} 8.8, \mathrm{H}_{7}, \mathrm{H}_{7^{\prime}}\right), 5.95\left(2 \mathrm{H}, \mathrm{dd},{ }^{3} J_{\mathrm{PH}} 34.1,{ }^{3} J_{\mathrm{HH}} 6.9, \mathrm{H}_{4}, \mathrm{H}_{4^{\prime}}\right)$, $4.18\left(2 \mathrm{H}, \mathrm{dd},{ }^{2} J_{\mathrm{PH}} 14.2,{ }^{3} J_{\mathrm{HH}} 6.9, \mathrm{H}_{5}, \mathrm{H}_{5^{\prime}}\right) . \delta_{\mathrm{C}}(150.9 \mathrm{MHz}$; $\mathrm{CDCl}_{3}$; TMS) 150.7 (d, $\left.{ }^{2} J_{\mathrm{PC}} 6.0, \mathrm{C}_{2}, \mathrm{C}_{2^{\prime}}\right), 143.3\left(\mathrm{~s}, \mathrm{C}_{15}, \mathrm{C}_{15^{\prime}}\right.$ ), $130.4\left(\mathrm{~s}, \mathrm{C}_{14}, \mathrm{C}_{14^{\prime}}\right.$ ), $129.4\left(\mathrm{~s}, \mathrm{C}_{9}, \mathrm{C}_{9^{\prime}}\right), 128.9\left(\mathrm{~s}, \mathrm{C}_{8}, \mathrm{C}_{8^{\prime}}\right), 128.5$ $\left(\mathrm{s}, \mathrm{C}_{12}, \mathrm{C}_{12^{\prime}}\right.$ ), 128.1 (s, $\mathrm{C}_{17}, \mathrm{C}_{17^{\prime}}, \mathrm{C}_{19}, \mathrm{C}_{19^{\prime}}$ ), 126.7-126.5 (br, $\mathrm{C}_{13}$, $\mathrm{C}_{13^{\prime}}, \mathrm{C}_{16}, \mathrm{C}_{16^{\prime}}, \mathrm{C}_{18}, \mathrm{C}_{18^{\prime}}, \mathrm{C}_{20}, \mathrm{C}_{20^{\prime}}$ ), $124.8\left(\mathrm{~d},{ }^{3} J_{\mathrm{PC}} 8.5, \mathrm{C}_{3}, \mathrm{C}_{3^{\prime}}\right.$ ), $123.5\left(\mathrm{~s}, \mathrm{C}_{11}, \mathrm{C}_{11^{\prime}}\right.$ ), $121.6\left(\mathrm{~s}, \mathrm{C}_{10}, \mathrm{C}_{10^{\prime}}\right.$ ), 121.2 (d, ${ }^{3} J_{\mathrm{PC}} 2.1, \mathrm{C}_{7}$, $\left.\mathrm{C}_{7^{\prime}}\right), 53.6\left(\mathrm{~s}, \mathrm{C}_{4}, \mathrm{C}_{4^{\prime}}\right) . \delta_{\mathrm{P}}\left(242.9 \mathrm{MHz} ; \mathrm{CDCl}_{3} ; \mathrm{H}_{3} \mathrm{PO}_{4}\right)-75.4$ $\left(\mathrm{s}, \mathrm{P}_{6}\right) \cdot \delta_{\mathrm{N}}\left(60.8 \mathrm{MHz} ; \mathrm{CDCl}_{3} ; \mathrm{NH}_{3}\right) 60.4\left(\mathrm{~d},{ }^{1} J_{\mathrm{PN}} 45.0, \mathrm{~N}_{5}, \mathrm{~N}_{5^{\prime}}\right)$. IR (KBr): $\nu=1193$ (POC), 1586, 1620 ( $\left.\mathrm{C}=\mathrm{C}_{\text {naphth }}\right), 2354$ $(\mathrm{PH}), 3414 \mathrm{~cm}^{-1}(\mathrm{NH})$; elemental analysis calcd (\%) for $\mathrm{C}_{34} \mathrm{H}_{27} \mathrm{~N}_{2} \mathrm{O}_{2} \mathrm{P}: \mathrm{C}$ 77.55, $\mathrm{H}$ 5.17, N 5.32, P 5.88; found: C77.35, $\mathrm{H} 5.01, \mathrm{~N} 5.49$, P 6.02 .

$\left(\Delta_{\mathrm{p}} R_{\mathrm{c}} S_{\mathrm{c}} / \Lambda_{\mathrm{p}} S_{\mathrm{c}} R_{\mathrm{c}}\right)$-6a-Hydro-5,14-diphenyldinaphtho[2,1- $\left.b, 2,1-h\right]$ 1,7,5,11,6-dioxadiazaphosphaspiro[5.5] undecadiene-7a,16a (4b). (0.3 g, 28.4\%, method B); m.p. $149-150{ }^{\circ} \mathrm{C} . \delta_{\mathrm{H}}(600.1 \mathrm{MHz}$; $\mathrm{CDCl}_{3}$; TMS $) 7.88\left(1 \mathrm{H}, \mathrm{d},{ }^{3} J_{\mathrm{HH}} 8.2, \mathrm{H}_{10}\right), 7.85\left(1 \mathrm{H}, \mathrm{d},{ }^{3} J_{\mathrm{HH}} 8.4\right.$, $\left.\mathrm{H}_{10^{\prime}}\right), 7.84\left(1 \mathrm{H}, \mathrm{d},{ }^{3} J_{\mathrm{HH}} 8.5, \mathrm{H}_{8}\right), 7.83\left(1 \mathrm{H}, \mathrm{d},{ }^{3} J_{\mathrm{HH}} 8.2, \mathrm{H}_{13}\right)$, $7.79\left(1 \mathrm{H}, \mathrm{d},{ }^{3} J_{\mathrm{HH}} 8.7, \mathrm{H}_{8^{\prime}}\right), 7.78\left(1 \mathrm{H}, \mathrm{d},{ }^{3} J_{\mathrm{HH}} 8.4, \mathrm{H}_{13^{\prime}}\right), 7.52$ $\left(1 \mathrm{H}, \mathrm{t},{ }^{3} J_{\mathrm{HH}} 7.5, \mathrm{H}_{12}\right), 7.48\left(1 \mathrm{H}, \mathrm{t},{ }^{3} J_{\mathrm{HH}} 7.5, \mathrm{H}_{12}\right), 7.45(2 \mathrm{H}, \mathrm{d}$, $\left.{ }^{3} J_{\mathrm{HH}} 8.0, \mathrm{H}_{16^{\prime}}, \mathrm{H}_{20^{\prime}}\right), 7.41\left(1 \mathrm{H}, \mathrm{t},{ }^{3} J_{\mathrm{HH}} 7.5, \mathrm{H}_{11}\right), 7.38(1 \mathrm{H}, \mathrm{t}$, $\left.{ }^{3} J_{\mathrm{HH}} 7.5, \mathrm{H}_{11^{\prime}}\right), 7.34\left(1 \mathrm{H}, \mathrm{d},{ }^{1} J_{\mathrm{PH}} 823.5, \mathrm{H}_{6}\right), 7.29(2 \mathrm{H}, \mathrm{t}$, $\left.{ }^{3} J_{\mathrm{HH}} 7.5, \mathrm{H}_{17^{\prime}}, \mathrm{H}_{19^{\prime}}\right), 7.22\left(2 \mathrm{H}, \mathrm{d},{ }^{3} J_{\mathrm{HH}} 7.5, \mathrm{H}_{18^{\prime}}\right), 7.19(1 \mathrm{H}, \mathrm{d}$, $\left.{ }^{3} J_{\mathrm{HH}} 8.5, \mathrm{H}_{7}\right), 7.16\left(1 \mathrm{H}, \mathrm{d},{ }^{3} J_{\mathrm{HH}} 8.7, \mathrm{H}_{7^{\prime}}\right), 7.02\left(2 \mathrm{H}, \mathrm{d},{ }^{3} J_{\mathrm{HH}} 7.3\right.$, $\left.\mathrm{H}_{16}, \mathrm{H}_{20}\right), 6.99\left(1 \mathrm{H}, \mathrm{d},{ }^{3} J_{\mathrm{HH}} 7.3, \mathrm{H}_{18}\right), 6.93\left(1 \mathrm{H}, \mathrm{t},{ }^{3} J_{\mathrm{HH}} 7.3\right.$, H17, H19), 5.87 (1 H, dd, $\left.{ }^{3} J_{\mathrm{PH}} 26.3,{ }^{3} J_{\mathrm{HH}} 6.7, \mathrm{H}_{4^{\prime}}\right), 5.81(1 \mathrm{H}$, $\left.\mathrm{dd},{ }^{3} J_{\mathrm{PH}} 33.1,{ }^{3} J_{\mathrm{HH}} 7.1, \mathrm{H}_{4}\right), 4.00\left(1 \mathrm{H}, \mathrm{dd},{ }^{2} J_{\mathrm{PH}} 13.8,{ }^{3} J_{\mathrm{HH}} 6.7\right.$, $\mathrm{H}_{5^{\prime}}$ ), $3.80\left(1 \mathrm{H}, \mathrm{dd},{ }^{2} J_{\mathrm{PH}} 16.2,{ }^{3} J_{\mathrm{HH}} 7.1, \mathrm{H}_{5}\right) . \delta_{\mathrm{C}}(150.9 \mathrm{MHz}$; $\mathrm{CDCl}_{3}$; TMS) 151.7 (d, ${ }^{2} J_{\mathrm{PC}} 5.9, \mathrm{C}_{2}$ ), $151.6\left(\mathrm{~d},{ }^{2} J_{\mathrm{PC}} 10.7, \mathrm{C}_{2^{\prime}}\right.$ ), 144.7 (s, $\mathrm{C}_{15^{\prime}}$ ), 143.9 (s, C 15 ), 131.5 (s, C $\left.{ }_{9}, \mathrm{C}_{9^{\prime}}\right), 129.9\left(\mathrm{~s}, \mathrm{C}_{13}\right.$ ), $129.2\left(\mathrm{~s}, \mathrm{C}_{19^{\prime}}\right.$ ), $129.7\left(\mathrm{~s}, \mathrm{C}_{13^{\prime}}\right), 128.6\left(\mathrm{~s}, \mathrm{C}_{19}\right), 127.8\left(\mathrm{~s}, \mathrm{C}_{18^{\prime}}\right), 127.4$ $\left(\mathrm{s}, \mathrm{C}_{12}, \mathrm{C}_{12^{\prime}}\right), 127.3\left(\mathrm{br}, \mathrm{C}_{18}, \mathrm{C}_{20^{\prime}}\right), 126.9\left(\mathrm{~s}, \mathrm{C}_{20}\right), 124.3\left(\mathrm{~s}, \mathrm{C}_{11}\right)$, $124.2\left(\mathrm{~s}, \mathrm{C}_{11^{\prime}}\right), 122.4\left(\mathrm{~s}, \mathrm{C}_{8}\right), 122.3\left(\mathrm{~s}, \mathrm{C}_{8^{\prime}}\right), 122.1\left(\mathrm{~s}, \mathrm{C}_{7^{\prime}}\right), 121.0$ $\left(\mathrm{s}, \mathrm{C}_{7}\right), 54.7\left(\mathrm{~s}, \mathrm{C}_{4^{\prime}}\right), 53.8\left(\mathrm{~s}, \mathrm{C}_{4}\right) . \delta_{\mathrm{P}}\left(242.9 \mathrm{MHz} ; \mathrm{CDCl}_{3} ; \mathrm{H}_{3} \mathrm{PO}_{4}\right)$ $-76.7\left(\mathrm{~s}, \mathrm{P}_{6}\right) . \delta_{\mathrm{N}}\left(60.8 \mathrm{MHz} ; \mathrm{CDCl}_{3} ; \mathrm{NH}_{3}\right) 61.9\left(\mathrm{~d},{ }^{1} J_{\mathrm{PN}} 30.0, \mathrm{~N}_{5}\right)$, $59.9\left(\mathrm{~d},{ }^{1} J_{\mathrm{PN}} 38.0, \mathrm{~N}_{5^{\prime}}\right.$ ). IR (KBr): $\nu=1194$ (POC), 1589, 1623 $\left(\mathrm{C}=\mathrm{C}_{\text {naphth }}\right), 2358(\mathrm{PH}), 3416 \mathrm{~cm}^{-1}(\mathrm{NH})$; elemental analysis 
calcd (\%) for $\mathrm{C}_{34} \mathrm{H}_{27} \mathrm{~N}_{2} \mathrm{O}_{2} \mathrm{P}$ : C 77.55, H 5.17, N 5.32, P 5.88; found: C77.38, H4.98, N 5.42, P 6.05.

$\left(\Delta_{\mathrm{p}} S_{\mathrm{c}} S_{\mathrm{c}} / \Lambda_{\mathrm{p}} R_{\mathrm{c}} R_{\mathrm{c}}\right)$-6a-Hydro-5,14-diphenyldinaphtho[2,1-b,2,1-h]1,7,5,11,6-dioxadiazaphosphaspiro[5.5]undecadiene-7a,16a (4c). M.p. $180-182{ }^{\circ} \mathrm{C} . \delta_{\mathrm{H}}\left(600.1 \mathrm{MHz} ; \mathrm{CDCl}_{3}\right.$; TMS $) 7.54(1 \mathrm{H}, \mathrm{d}$, $\left.{ }^{1} J_{\mathrm{PH}} 848.6, \mathrm{H}_{6}\right), 7.14\left(2 \mathrm{H}, \mathrm{d},{ }^{3} J_{\mathrm{HH}} 8.6, \mathrm{H}_{7}\right), 5.74(2 \mathrm{H}, \mathrm{dd}$, $\left.{ }^{3} J_{\mathrm{PH}} 25.6,{ }^{3} J_{\mathrm{HH}} 6.1, \mathrm{H}_{4}\right), 3.58\left(2 \mathrm{H}, \mathrm{dd},{ }^{2} J_{\mathrm{PH}} 17.3,{ }^{3} J_{\mathrm{HH}} 5.6, \mathrm{H}_{5}\right)$. $\delta_{\mathrm{P}}\left(242.9 \mathrm{MHz} ; \mathrm{CDCl}_{3} ; \mathrm{H}_{3} \mathrm{PO}_{4}\right)-80.7\left(\mathrm{~s}, \mathrm{P}_{6}\right) . \delta_{\mathrm{N}}(60.8 \mathrm{MHz} ;$ $\left.\mathrm{CDCl}_{3} ; \mathrm{NH}_{3}\right) 64.0\left(\mathrm{~d},{ }^{1} J_{\mathrm{PN}} 38.0, \mathrm{~N}_{5}, \mathrm{~N}_{5^{\prime}}\right.$ ). Individual substance could not be isolated.

$\left(\Delta_{\mathrm{P}} R_{\mathrm{c}} R_{\mathrm{c}} / \Lambda_{\mathrm{P}} S_{\mathrm{c}} S_{\mathrm{c}}\right)$-6a-Hydro-5,14-di ( $p$-fluorophenyl)dinaphtho [2,1-b,2,1- $h]-1,7,5,11,6$-dioxadiazaphosphaspiro[5.5] undecadiene7a,16a (5a). (0.34 g, 30.1\%, method B); m.p. 171-173 ${ }^{\circ} \mathrm{C}$. $\delta_{\mathrm{H}}\left(600.1 \mathrm{MHz} ; \mathrm{CDCl}_{3} ; \mathrm{TMS}\right) 7.84\left(2 \mathrm{H}, \mathrm{d},{ }^{3} \mathrm{JHH}_{\mathrm{HH}} 8.3, \mathrm{H}_{10}, \mathrm{H}_{10^{\prime}}\right)$, $7.81\left(2 \mathrm{H}, \mathrm{d},{ }^{3} J_{\mathrm{HH}} 8.3, \mathrm{H}_{13}, \mathrm{H}_{13^{\prime}}\right), 7.76\left(2 \mathrm{H}, \mathrm{d},{ }^{3} \mathrm{~J}_{\mathrm{HH}} 8.7, \mathrm{H}_{8}, \mathrm{H}_{8^{\prime}}\right)$, $7.51\left(2 \mathrm{H}, \mathrm{t},{ }^{3} \mathrm{~J}_{\mathrm{HH}} 8.3, \mathrm{H}_{12}, \mathrm{H}_{12^{\prime}}\right), 7.39\left(2 \mathrm{H}, \mathrm{t},{ }^{3} J_{\mathrm{HH}} 8.3, \mathrm{H}_{11}\right.$, $\left.\mathrm{H}_{11^{\prime}}\right), 7.26\left(4 \mathrm{H}, \mathrm{dd},{ }^{3} J_{\mathrm{HH}} 8.6,{ }^{4} J_{\mathrm{FH}} 5.7, \mathrm{H}_{16}, \mathrm{H}_{20}, \mathrm{H}_{16^{\prime}}, \mathrm{H}_{20^{\prime}}\right), 7.09$ $\left(1 \mathrm{H}, \mathrm{d},{ }^{1} J_{\mathrm{PH}} 792.1, \mathrm{H}_{6}\right), 7.08\left(2 \mathrm{H}, \mathrm{d},{ }^{3} J_{\mathrm{HH}} 8.7, \mathrm{H}_{7}, \mathrm{H}_{7^{\prime}}\right), 6.88$ $\left(4 \mathrm{H}, \mathrm{t},{ }^{3} \mathrm{~J}_{\mathrm{HH}} 8.7, \mathrm{H}_{17}, \mathrm{H}_{19}, \mathrm{H}_{17^{\prime}}, \mathrm{H}_{19}\right), 5.91\left(2 \mathrm{H}, \mathrm{dd},{ }^{3} J_{\mathrm{PH}} 34.1\right.$, $\left.{ }^{3} J_{\mathrm{HH}} 6.9, \mathrm{H}_{4}, \mathrm{H}_{4^{\prime}}\right), 4.17\left(2 \mathrm{H}, \mathrm{dd},{ }^{2} J_{\mathrm{PH}} 14.2,{ }^{3} J_{\mathrm{HH}} 6.9, \mathrm{H}_{5}, \mathrm{H}_{5^{\prime}}\right.$ ). $\delta_{\mathrm{C}}\left(150.9 \mathrm{MHz} ; \mathrm{CDCl}_{3}\right.$; TMS) $161.9\left(\mathrm{~d},{ }^{1} J_{\mathrm{CF}} 245.3, \mathrm{C}_{18}, \mathrm{C}_{18^{\prime}}\right)$, $150.8\left(\mathrm{~d},{ }^{2} J_{\mathrm{PC}} 5.8, \mathrm{C}_{2}, \mathrm{C}_{2^{\prime}}\right), 139.4\left(\mathrm{~d},{ }^{4} J_{\mathrm{CF}} 2.0, \mathrm{C}_{15}, \mathrm{C}_{15^{\prime}}\right), 130.5$ (s, $\left.\mathrm{C}_{14}, \mathrm{C}_{14^{\prime}}\right), 129.7\left(\mathrm{~s}, \mathrm{C}_{9}, \mathrm{C}_{9^{\prime}}\right), 129.4\left(\mathrm{~s}, \mathrm{C}_{8}, \mathrm{C}_{8^{\prime}}\right), 128.8\left(\mathrm{~s}, \mathrm{C}_{13}, \mathrm{C}_{13^{\prime}}\right.$ ), 128.5-128.3 (br, $\mathrm{C}_{16}, \mathrm{C}_{16^{\prime}}, \mathrm{C}_{20}, \mathrm{C}_{20^{\prime}}$ ), $126.9\left(\mathrm{~s}, \mathrm{C}_{12}, \mathrm{C}_{12^{\prime}}\right), 124.7$ (d, $\left.{ }^{3} J_{\mathrm{PC}} 8.2, \mathrm{C}_{3}, \mathrm{C}_{3^{\prime}}\right), 123.8\left(\mathrm{~s}, \mathrm{C}_{11}, \mathrm{C}_{11^{\prime}}\right), 121.5\left(\mathrm{~s}, \mathrm{C}_{10}, \mathrm{C}_{10^{\prime}}\right.$ ), $121.4\left(\mathrm{~s}, \mathrm{C}_{7}, \mathrm{C}_{7^{\prime}}\right), 115.1$ (d, $\left.{ }^{2} J_{\mathrm{CF}} 20.0, \mathrm{C}_{17}, \mathrm{C}_{17^{\prime}}, \mathrm{C}_{19}, \mathrm{C}_{19^{\prime}}\right), 53.2$ $\left(\mathrm{s}, \mathrm{C}_{4}, \mathrm{C}_{4}\right) . \delta_{\mathrm{P}}\left(242.9 \mathrm{MHz} ; \mathrm{CDCl}_{3} ; \mathrm{H}_{3} \mathrm{PO}_{4}\right)-75.2\left(\mathrm{~s}, \mathrm{P}_{6}\right) \cdot \delta_{\mathrm{N}}$ $\left(60.8 \mathrm{MHz} ; \mathrm{CDCl}_{3} ; \mathrm{NH}_{3}\right) 61.0\left(\mathrm{~d},{ }^{1} J_{\mathrm{PN}} 58.0, \mathrm{~N}_{5}, \mathrm{~N}_{5^{\prime}}\right) . \delta_{\mathrm{F}}$ (376.5 MHz; $\left.\mathrm{CDCl}_{3} ; \mathrm{C}_{6} \mathrm{~F}_{6}\right)-116.0\left(\mathrm{~s}, \mathrm{~F}_{18}, \mathrm{~F}_{18^{\prime}}\right)$. IR (KBr): $\nu=$ 1195 (POC), 1588, 1623 (C= $\left.\mathrm{C}_{\text {naphth }}\right), 2364(\mathrm{PH}), 3420 \mathrm{~cm}^{-1}$ $(\mathrm{NH})$; elemental analysis calcd (\%) for $\mathrm{C}_{34} \mathrm{H}_{25} \mathrm{~F}_{2} \mathrm{~N}_{2} \mathrm{O}_{2} \mathrm{P}$ : C 72.59, H 4.48, N 4.98, P 5.51; found: C 72.66, H 4.31, N 4.87, P 5.32 .

$\left(\Delta_{\mathrm{P}} R_{\mathrm{c}} S_{\mathrm{c}} / \Lambda_{\mathrm{P}} S_{\mathrm{c}} R_{\mathrm{c}}\right)$-6a-Hydro-5,14-di( $p$-fluorophenyl)dinaphtho [2,1-b,2,1-h]-1,7,5,11,6-dioxadiazaphosphaspiro[5.5] undecadiene7a,16a (5b). (0.28 g, 24.8\%, method B); m.p. $141-143{ }^{\circ} \mathrm{C}$. $\delta_{\mathrm{H}}\left(600.1 \mathrm{MHz} ; \mathrm{CDCl}_{3} ; \mathrm{TMS}\right) 7.89\left(1 \mathrm{H}, \mathrm{d},{ }^{3} \mathrm{~J}_{\mathrm{HH}} 8.0, \mathrm{H}_{10^{\prime}}\right), 7.85$ $\left(1 \mathrm{H}, \mathrm{d},{ }^{3} \mathrm{JHH}_{\mathrm{HH}} 8.0, \mathrm{H}_{10}\right), 7.84\left(1 \mathrm{H}, \mathrm{d},{ }^{3} \mathrm{~J}_{\mathrm{HH}} 8.8, \mathrm{H}_{8^{\prime}}\right), 7.80(1 \mathrm{H}, \mathrm{d}$, $\left.{ }^{3} J_{\mathrm{HH}} 7.7, \mathrm{H}_{8}\right), 7.78\left(1 \mathrm{H}, \mathrm{d},{ }^{3} J_{\mathrm{HH}} 8.1, \mathrm{H}_{13^{\prime}}\right), 7.73\left(1 \mathrm{H}, \mathrm{d},{ }^{3} J_{\mathrm{HH}} 8.5\right.$, $\left.\mathrm{H}_{13}\right), 7.54\left(1 \mathrm{H}, \mathrm{t},{ }^{3} J_{\mathrm{HH}} 7.2, \mathrm{H}_{12^{\prime}}\right), 7.48\left(1 \mathrm{H}, \mathrm{t},{ }^{3} J_{\mathrm{HH}} 7.5, \mathrm{H}_{12}\right)$, $7.43\left(1 \mathrm{H}, \mathrm{t},{ }^{3} \mathrm{~J}_{\mathrm{HH}} 7.5, \mathrm{H}_{11^{\prime}}\right), 7.39\left(3 \mathrm{H}, \mathrm{m}, \mathrm{H}_{11}, \mathrm{H}_{16^{\prime}}, \mathrm{H}_{20^{\prime}}\right), 7.32$ $\left(1 \mathrm{H}, \mathrm{d},{ }^{1} J_{\mathrm{PH}} 824.0, \mathrm{H}_{6}\right), 7.18\left(1 \mathrm{H}, \mathrm{d},{ }^{3} J_{\mathrm{HH}} 8.9, \mathrm{H}_{7^{\prime}}\right), 7.16(1 \mathrm{H}, \mathrm{d}$, $\left.{ }^{3} J_{\mathrm{HH}} 9.2, \mathrm{H}_{7}\right), 6.95\left(2 \mathrm{H}, \mathrm{dd},{ }^{3} J_{\mathrm{HH}} 9.2, \mathrm{H}_{17^{\prime}}, \mathrm{H}_{19^{\prime}}\right), 6.91(2 \mathrm{H}, \mathrm{dd}$, $\left.{ }^{3} J_{\mathrm{HH}} 8.8,{ }^{4} J_{\mathrm{FH}} 5.4, \mathrm{H}_{16}, \mathrm{H}_{20}\right), 6.58\left(1 \mathrm{H}, \mathrm{dd},{ }^{3} \mathrm{~J}_{\mathrm{HH}} 8.8, \mathrm{H}_{17}, \mathrm{H}_{19}\right)$, $5.82\left(1 \mathrm{H}, \mathrm{dd},{ }^{2} J_{\mathrm{PH}} 27.7,{ }^{3} J_{\mathrm{HH}} 6.8, \mathrm{H}_{4^{\prime}}\right), 5.76\left(1 \mathrm{H}, \mathrm{dd},{ }^{2} J_{\mathrm{PH}} 33.6\right.$, $\left.{ }^{3} J_{\mathrm{HH}} 7.6, \mathrm{H}_{4}\right), 3.95\left(1 \mathrm{H}, \mathrm{dd},{ }^{3} J_{\mathrm{PH}} 14.0,{ }^{3} J_{\mathrm{HH}} 6.8, \mathrm{H}_{5^{\prime}}\right), 3.77(1 \mathrm{H}$, dd, $\left.{ }^{2} J_{\mathrm{PH}} 16.8,{ }^{3} J_{\mathrm{HH}} 7.2, \mathrm{H}_{5}\right) . \delta_{\mathrm{C}}\left(150.9 \mathrm{MHz} ; \mathrm{CDCl}_{3}\right.$; TMS) 162.0 (d, $\left.{ }^{1} J_{\mathrm{CF}} 247.3, \mathrm{C}_{18^{\prime}}\right), 161.6\left(\mathrm{~d},{ }^{1} J_{\mathrm{CF}} 244.8, \mathrm{C}_{18^{\prime}}\right), 151.1\left(\mathrm{~d},{ }^{2} J_{\mathrm{PC}} 9.9\right.$, $\mathrm{C}_{2^{\prime}}$ ), $151.0\left(\mathrm{~d},{ }^{2} J_{\mathrm{PC}} 14.8, \mathrm{C}_{2}\right), 139.8\left(\mathrm{~d},{ }^{3} J_{\mathrm{PC}} 3.0, \mathrm{C}_{15^{\prime}}\right), 139.1$ $\left(\mathrm{d},{ }^{3} J_{\mathrm{PC}} 3.4, \mathrm{C}_{15}\right), 130.7\left(\mathrm{~s}, \mathrm{C}_{14^{\prime}}\right), 130.6\left(\mathrm{~s}, \mathrm{C}_{14}\right), 129.8\left(\mathrm{~d},{ }^{4} J_{\mathrm{PC}} 10.0\right.$, $\left.\mathrm{C}_{8}\right), 129.4\left(\mathrm{~d},{ }^{4} \mathrm{JCC}_{\mathrm{PC}} 23.6, \mathrm{C}_{8^{\prime}}\right), 128.9\left(\mathrm{~s}, \mathrm{C}_{10^{\prime}}\right), 128.8\left(\mathrm{~s}, \mathrm{C}_{10}\right), 128.3$ $\left(\mathrm{d},{ }^{3} J_{\mathrm{FC}} 8.5, \mathrm{C}_{16^{\prime}}, \mathrm{C}_{20^{\prime}}\right), 128.0\left(\mathrm{~d},{ }^{3} \mathrm{JC}_{\mathrm{FC}} 8.2, \mathrm{C}_{16}, \mathrm{C}_{20}\right), 127.1$ (s, $\left.\mathrm{C}_{12^{\prime}}\right), 126.9\left(\mathrm{~s}, \mathrm{C}_{12}\right), 124.8\left(\mathrm{~d},{ }^{3} \mathrm{JC}_{\mathrm{PC}} 9.1, \mathrm{C}_{3^{\prime}}\right), 123.9\left(\mathrm{~s}, \mathrm{C}_{11^{\prime}}\right), 123.7$ $\left(\mathrm{s}, \mathrm{C}_{11}\right), 122.9\left(\mathrm{~d},{ }^{3} \mathrm{~J}_{\mathrm{PC}} 10.9, \mathrm{C}_{3}\right), 121.6\left(\mathrm{~s}, \mathrm{C}_{13}\right), 121.5\left(\mathrm{~s}, \mathrm{C}_{13}\right)$, $121.4\left(\mathrm{~d},{ }^{3} J_{\mathrm{PC}} 2.7, \mathrm{C}_{7}\right), 120.4\left(\mathrm{~d},{ }^{3} J_{\mathrm{PC}} 1.3, \mathrm{C}_{7^{\prime}}\right), 115.4\left(\mathrm{~d},{ }^{2} J_{\mathrm{FC}} 21.5\right.$, $\left.\mathrm{C}_{17^{\prime}}, \mathrm{C}_{19^{\prime}}\right), 114.7\left(\mathrm{~d},{ }^{2} J_{\mathrm{PC}} 21.3, \mathrm{C}_{17}, \mathrm{C}_{19}\right), 53.3\left(\mathrm{~s}, \mathrm{C}_{4^{\prime}}\right), 52.6\left(\mathrm{~s}, \mathrm{C}_{4}\right)$.
$\delta_{\mathrm{P}}\left(242.9 \mathrm{MHz} ; \mathrm{CDCl}_{3} ; \mathrm{H}_{3} \mathrm{PO}_{4}\right)-76.6\left(\mathrm{~s}, \mathrm{P}_{6}\right) . \delta_{\mathrm{N}}(60.8 \mathrm{MHz} ;$ $\left.\mathrm{CDCl}_{3} ; \mathrm{NH}_{3}\right) 62.4\left(\mathrm{~d},{ }^{1} J_{\mathrm{PN}} 30.0, \mathrm{~N}_{5}\right), 60.2\left(\mathrm{~d},{ }^{1} J_{\mathrm{PN}} 45.0, \mathrm{~N}_{5^{\prime}}\right.$ ). $\delta_{\mathrm{F}}\left(376.5 \mathrm{MHz} ; \mathrm{CDCl}_{3} ; \mathrm{C}_{6} \mathrm{~F}_{6}\right)-115.8\left(\mathrm{~s}, \mathrm{~F}_{18^{\prime}}\right),-116.6\left(\mathrm{~s}, \mathrm{~F}_{18}\right)$. IR (KBr): $\nu=1191$ (POC), 1586, $1624\left(\mathrm{C}=\mathrm{C}_{\text {naphth }}\right), 2358$ $(\mathrm{PH}), 3422 \mathrm{~cm}^{-1}(\mathrm{NH})$; elemental analysis calcd (\%) for $\mathrm{C}_{34} \mathrm{H}_{25} \mathrm{~F}_{2} \mathrm{~N}_{2} \mathrm{O}_{2} \mathrm{P}: \mathrm{C}$ 72.59, $\mathrm{H}$ 4.48, N 4.98, P 5.51; found: $\mathrm{C} 72.74, \mathrm{H} 4.59, \mathrm{~N} 4.83$, P 5.41.

$\left(\Delta_{\mathrm{P}} S_{\mathrm{c}} S_{\mathrm{c}} / \Lambda_{\mathrm{P}} R_{\mathrm{c}} R_{\mathrm{c}}\right)$-6a-Hydro-5,14-di $(p$-fluorophenyl)dinaphtho [2,1-b,2,1-h]-1,7,5,11,6-dioxadiazaphosphaspiro[5.5] undecadiene7a,16a (5c). M.p. $171-173{ }^{\circ} \mathrm{C} . \delta_{\mathrm{H}}\left(600.1 \mathrm{MHz} ; \mathrm{CDCl}_{3}\right.$; TMS) 7.52 $\left(1 \mathrm{H}, \mathrm{d},{ }^{1} J_{\mathrm{PH}} 849.0, \mathrm{H}_{6}\right), 5.70\left(2 \mathrm{H}, \mathrm{dd},{ }^{3} J_{\mathrm{PH}} 25.0,{ }^{3} J_{\mathrm{HH}} 6.8, \mathrm{H}_{4}\right.$, $\left.\mathrm{H}_{4^{\prime}}\right), 3.56\left(2 \mathrm{H}, \mathrm{dd},{ }^{2} J_{\mathrm{PH}} 17.6,{ }^{3} J_{\mathrm{HH}} 5.7, \mathrm{H}_{5}, \mathrm{H}_{5^{\prime}}\right) . \delta_{\mathrm{P}}(242.9 \mathrm{MHz}$; $\left.\mathrm{CDCl}_{3} ; \mathrm{H}_{3} \mathrm{PO}_{4}\right)-80.5\left(\mathrm{~s}, \mathrm{P}_{6}\right) . \delta_{\mathrm{N}}\left(60.8 \mathrm{MHz} ; \mathrm{CDCl}_{3} ; \mathrm{NH}_{3}\right) 64.2$ $\left(\mathrm{d},{ }^{1} J_{\mathrm{PN}} 45.0, \mathrm{~N}_{5}, \mathrm{~N}_{5^{\prime}}\right.$ ). $\delta_{\mathrm{F}}\left(376.5 \mathrm{MHz} ; \mathrm{CDCl}_{3} ; \mathrm{C}_{6} \mathrm{~F}_{6}\right)-115.5$ $\left(\mathrm{s}, \mathrm{F}_{18}, \mathrm{~F}_{18}\right.$ ). Individual substance could not be isolated.

$\left(\Delta_{\mathrm{p}} R_{\mathrm{c}} R_{\mathrm{c}} / \Lambda_{\mathrm{P}} S_{\mathrm{c}} S_{\mathrm{c}}\right)$-6a-Hydro-2,11-dibromo-5,14-diphenyldinaphtho[2,1-b,2,1-h]-1,7,5,11,6-dioxadiazaphosphaspiro[5.5] undecadiene-7a,16a (6a). (0.45 g, 32.8\%, method B); m.p. $189-192{ }^{\circ} \mathrm{C} . \delta_{\mathrm{H}}\left(600.1 \mathrm{MHz} ; \mathrm{CDCl}_{3}\right.$; TMS $) 7.98(2 \mathrm{H}, \mathrm{br}$, $\left.\mathrm{H}_{10}, \mathrm{H}_{10^{\prime}}\right), 7.71\left(2 \mathrm{H}, \mathrm{d},{ }^{3} J_{\mathrm{HH}} 9.1, \mathrm{H}_{13}, \mathrm{H}_{13^{\prime}}\right), 7.65(2 \mathrm{H}, \mathrm{d}$, $\left.{ }^{3} J_{\mathrm{HH}} 8.7, \mathrm{H}_{8}, \mathrm{H}_{8^{\prime}}\right), 7.55\left(2 \mathrm{H}, \mathrm{t},{ }^{3} J_{\mathrm{HH}} 9.1, \mathrm{H}_{12}, \mathrm{H}_{12^{\prime}}\right), 7.27(4 \mathrm{H}$, br, $\left.\mathrm{H}_{16}, \mathrm{H}_{20}, \mathrm{H}_{16^{\prime}}, \mathrm{H}_{20^{\prime}}\right), 7.19\left(6 \mathrm{H}, \mathrm{m}, \mathrm{H}_{17}, \mathrm{H}_{18}, \mathrm{H}_{19}, \mathrm{H}_{17^{\prime}}, \mathrm{H}_{18^{\prime}}\right.$, $\left.\mathrm{H}_{19^{\prime}}\right), 7.08\left(1 \mathrm{H}, \mathrm{d},{ }^{1} J_{\mathrm{PH}} 790.4, \mathrm{H}_{6}\right), 7.09\left(2 \mathrm{H}, \mathrm{d},{ }^{3} J_{\mathrm{HH}} 8.7, \mathrm{H}_{7}\right.$, $\left.\mathrm{H}_{7^{\prime}}\right), 5.89\left(2 \mathrm{H}, \mathrm{dd},{ }^{3} J_{\mathrm{PH}} 34.1,{ }^{3} \mathrm{JHH}_{\mathrm{HH}} 6.7, \mathrm{H}_{4}, \mathrm{H}_{4^{\prime}}\right), 4.17(2 \mathrm{H}, \mathrm{dd}$, ${ }^{2} J_{\mathrm{PH}} 14.0,{ }^{3} J_{\mathrm{HH}} 6.7, \mathrm{H}_{5}, \mathrm{H}_{5^{\prime}}$ ). $\delta_{\mathrm{C}}\left(150.9 \mathrm{MHz} ; \mathrm{CDCl}_{3} ; \mathrm{TMS}\right) 151.7$ $\left(\mathrm{s}, \mathrm{C}_{2}, \mathrm{C}_{2^{\prime}}\right.$ ), $143.5\left(\mathrm{~s}, \mathrm{C}_{15}, \mathrm{C}_{15^{\prime}}\right), 131.1\left(\mathrm{~s}, \mathrm{C}_{14}, \mathrm{C}_{14^{\prime}}\right), 131.0$ (s, $\mathrm{C}_{10}$, $\mathrm{C}_{10^{\prime}}$ ), $130.5\left(\mathrm{~s}, \mathrm{C}_{12}, \mathrm{C}_{12^{\prime}}\right), 129.4\left(\mathrm{~s}, \mathrm{C}_{9}, \mathrm{C}_{9^{\prime}}\right), 128.9\left(\mathrm{~s}, \mathrm{C}_{17}, \mathrm{C}_{19}\right.$, $\left.\mathrm{C}_{17^{\prime}}, \mathrm{C}_{19^{\prime}}\right), 128.7\left(\mathrm{~s}, \mathrm{C}_{8}, \mathrm{C}_{8^{\prime}}\right), 127.1-126.9$ (br, $\mathrm{C}_{16}, \mathrm{C}_{18}, \mathrm{C}_{20}, \mathrm{C}_{16^{\prime}}$, $\left.\mathrm{C}_{18^{\prime}}, \mathrm{C}_{20^{\prime}}\right), 125.4\left(\mathrm{~d},{ }^{3} J_{\mathrm{PC}} 8.6, \mathrm{C}_{3}, \mathrm{C}_{3^{\prime}}\right), 124.0\left(\mathrm{~s}, \mathrm{C}_{13}, \mathrm{C}_{13^{\prime}}\right), 123.0$ $\left(\mathrm{s}, \mathrm{C}_{7}, \mathrm{C}_{7^{\prime}}\right), 117.9\left(\mathrm{~s}, \mathrm{C}_{11}, \mathrm{C}_{11^{\prime}}\right), 52.2\left(\mathrm{~s}, \mathrm{C}_{4}, \mathrm{C}_{4^{\prime}}\right) . \delta_{\mathrm{P}}(242.9 \mathrm{MHz} ;$ $\left.\mathrm{CDCl}_{3} ; \mathrm{H}_{3} \mathrm{PO}_{4}\right)-76.4\left(\mathrm{~s}, \mathrm{P}_{6}\right) . \delta_{\mathrm{N}}\left(60.8 \mathrm{MHz} ; \mathrm{CDCl}_{3} ; \mathrm{NH}_{3}\right) 60.4$ (d, ${ }^{1} J_{\mathrm{PN}} 35.0, \mathrm{~N}_{5}, \mathrm{~N}_{5^{\prime}}$ ). IR (KBr): $\nu=1199$ (POC), 1587, 1619 $\left(\mathrm{C}=\mathrm{C}_{\text {naphth }}\right), 2353(\mathrm{PH}), 3419 \mathrm{~cm}^{-1}(\mathrm{NH})$; elemental analysis calcd (\%) for $\mathrm{C}_{34} \mathrm{H}_{25} \mathrm{Br}_{2} \mathrm{~N}_{2} \mathrm{O}_{2} \mathrm{P}$ : C 59.67, H 3.68, Br 23.35, N 4.09, P 4.53; found: C 59.86, H 3.49, Br 23.54, N 3.89, P 4.48.

$\left(\Delta_{\mathrm{P}} R_{\mathrm{c}} S_{\mathrm{c}} / \Lambda_{\mathrm{P}} S_{\mathrm{c}} R_{\mathrm{c}}\right)$-6a-Hydro-2,11-dibromo-5,14-diphenyldinaphtho[2,1- $b, 2,1-h]-1,7,5,11,6$-dioxadiazaphosphaspiro[5.5] undecadiene-7a,16a (6b). $\quad(0.3 \quad \mathrm{~g}, \quad 21.8 \%$, method $\mathbf{B})$; m.p. $156-158{ }^{\circ} \mathrm{C} . \delta_{\mathrm{H}}\left(600.1 \mathrm{MHz} ; \mathrm{CDCl}_{3}\right.$; TMS) $8.02(1 \mathrm{H}, \mathrm{d}$, $\left.{ }^{4} J_{\mathrm{HH}} 1.7, \mathrm{H}_{10^{\prime}}\right), 7.99\left(1 \mathrm{H}, \mathrm{d},{ }^{4} J_{\mathrm{HH}} 1.9, \mathrm{H}_{10}\right), 7.73(1 \mathrm{H}, \mathrm{d}$, $\left.{ }^{3} J_{\mathrm{HH}} 8.7, \mathrm{H}_{8^{\prime}}\right), 7.67\left(2 \mathrm{H}, \mathrm{d},{ }^{3} J_{\mathrm{HH}} 9.1, \mathrm{H}_{8}, \mathrm{H}_{13^{\prime}}\right), 7.63(1 \mathrm{H}, \mathrm{d}$, $\left.{ }^{3} J_{\mathrm{HH}} 9.1, \mathrm{H}_{13}\right), 7.56\left(1 \mathrm{H}, \mathrm{dd},{ }^{3} J_{\mathrm{HH}} 9.1,{ }^{4} J_{\mathrm{HH}} 1.7, \mathrm{H}_{12}\right), 7.52(1 \mathrm{H}$, $\left.\mathrm{dd},{ }^{3} J_{\mathrm{HH}} 9.1,{ }^{4} J_{\mathrm{HH}} 1.9, \mathrm{H}_{12}\right), 7.33\left(1 \mathrm{H}, \mathrm{d},{ }^{1} J_{\mathrm{PH}} 828.0, \mathrm{H}_{6}\right), 7.28$ ( $\left.4 \mathrm{H}, \mathrm{m}, \mathrm{H}_{16^{\prime}}, \mathrm{H}_{17^{\prime}}, \mathrm{H}_{19^{\prime}}, \mathrm{H}_{20^{\prime}}\right), 7.23\left(1 \mathrm{H}, \mathrm{m}, \mathrm{H}_{18^{\prime}}\right), 7.19(1 \mathrm{H}, \mathrm{d}$, $\left.{ }^{3} J_{\mathrm{HH}} 8.7, \mathrm{H}_{7^{\prime}}\right), 7.16\left(1 \mathrm{H}, \mathrm{d},{ }^{3} J_{\mathrm{HH}} 9.1, \mathrm{H}_{7}\right), 7.01\left(1 \mathrm{H}, \mathrm{m}, \mathrm{H}_{18}\right)$, $6.96\left(4 \mathrm{H}, \mathrm{br}, \mathrm{H}_{16}, \mathrm{H}_{17}, \mathrm{H}_{19}, \mathrm{H}_{20}\right), 5.78\left(1 \mathrm{H}, \mathrm{dd},{ }^{2} J_{\mathrm{PH}} 27.5\right.$, $\left.{ }^{3} J_{\mathrm{HH}} 6.9, \mathrm{H}_{4^{\prime}}\right), 5.74\left(1 \mathrm{H}, \mathrm{dd},{ }^{2} J_{\mathrm{PH}} 33.7,{ }^{3} J_{\mathrm{HH}} 7.3, \mathrm{H}_{4}\right), 3.95(1 \mathrm{H}$, $\left.\mathrm{dd},{ }^{3} J_{\mathrm{PH}} 13.8,{ }^{3} J_{\mathrm{HH}} 6.5, \mathrm{H}_{5^{\prime}}\right), 3.77\left(1 \mathrm{H}, \mathrm{dd},{ }^{2} J_{\mathrm{PH}} 16.3,{ }^{3} J_{\mathrm{HH}} 7.3\right.$, $\left.\mathrm{H}_{5}\right) . \delta_{\mathrm{C}}\left(150.9 \mathrm{MHz} ; \mathrm{CDCl}_{3}\right.$; TMS) $151.8\left(\mathrm{~d},{ }^{2} J_{\mathrm{PC}} 16.2, \mathrm{C}_{2^{\prime}}\right), 151.7$ (d, ${ }^{2} J_{\mathrm{PC}} 20.3, \mathrm{C}_{2}$ ), $144.0\left(\mathrm{~s}, \mathrm{C}_{15^{\prime}}\right.$ ), $143.4\left(\mathrm{~s}, \mathrm{C}_{15}\right), 131.3$ (s, $\mathrm{C}_{9^{\prime}}$ ), $131.2\left(\mathrm{~s}, \mathrm{C}_{10^{\prime}}\right), 131.1\left(\mathrm{~s}, \mathrm{C}_{10}\right), 130.9\left(\mathrm{~s}, \mathrm{C}_{9}\right), 130.5\left(\mathrm{~s}, \mathrm{C}_{12^{\prime}}\right), 130.4$ (s, $\mathrm{C}_{12}$ ), 129.8 (s, $\left.\mathrm{C}_{14^{\prime}}\right), 129.7$ (s, $\mathrm{C}_{14}$ ), 129.1 (br, $\mathrm{C}_{8^{\prime}}, \mathrm{C}_{17^{\prime}}, \mathrm{C}_{19^{\prime}}$ ), $128.7\left(\mathrm{~s}, \mathrm{C}_{8}\right), 128.5\left(\mathrm{~s}, \mathrm{C}_{17}, \mathrm{C}_{19}\right), 127.8\left(\mathrm{~s}, \mathrm{C}_{18}\right), 127.2\left(\mathrm{~s}, \mathrm{C}_{18}\right)$, $127.0\left(\mathrm{~s}, \mathrm{C}_{16^{\prime}}, \mathrm{C}_{20^{\prime}}\right), 126.6\left(\mathrm{~s}, \mathrm{C}_{16}, \mathrm{C}_{20}\right), 125.2\left(\mathrm{~d},{ }^{3} J_{\mathrm{PC}} 7.7, \mathrm{C}_{3^{\prime}}\right)$, $124.0\left(\mathrm{~s}, \mathrm{C}_{13^{\prime}}\right), 123.9\left(\mathrm{~s}, \mathrm{C}_{13}\right), 123.5\left(\mathrm{~d},{ }^{3} J_{\mathrm{PC}} 10.6, \mathrm{C}_{3}\right), 123.4$ $\left(\mathrm{d},{ }^{3} \mathrm{JCC}_{\mathrm{PC}} 2.7, \mathrm{C}_{7}\right), 123.0\left(\mathrm{br}, \mathrm{C}_{7^{\prime}}\right), 117.9\left(\mathrm{~s}, \mathrm{C}_{11^{\prime}}\right), 117.7\left(\mathrm{~s}, \mathrm{C}_{11}\right)$, 
$54.5\left(\mathrm{~s}, \mathrm{C}_{4^{\prime}}\right), 53.6\left(\mathrm{~s}, \mathrm{C}_{4}\right) \cdot \delta_{\mathrm{P}}\left(242.94 \mathrm{MHz} ; \mathrm{CDCl}_{3} ; \mathrm{H}_{3} \mathrm{PO}_{4}\right)-77.7$ $\left(\mathrm{s}, \mathrm{P}_{6}\right) . \delta_{\mathrm{N}}\left(60.8 \mathrm{MHz} ; \mathrm{CDCl}_{3} ; \mathrm{NH}_{3}\right) 61.9\left(\mathrm{~d},{ }^{1} J_{\mathrm{PN}} 30.0, \mathrm{~N}_{5}\right)$, $59.9\left(\mathrm{~d},{ }^{1} J_{\mathrm{PN}} 40.0, \mathrm{~N}_{5^{\prime}}\right.$ ). IR (KBr): $\nu=1191$ (POC), 1586, 1617 $\left(\mathrm{C}=\mathrm{C}_{\text {naphth }}\right), 2370(\mathrm{PH}), 3422 \mathrm{~cm}^{-1}(\mathrm{NH})$; elemental analysis calcd (\%) for $\mathrm{C}_{34} \mathrm{H}_{25} \mathrm{Br}_{2} \mathrm{~N}_{2} \mathrm{O}_{2} \mathrm{P}$ : C 59.67, $\mathrm{H}$ 3.68, $\mathrm{Br}$ 23.35, N 4.09, P 4.53; found: C 59.75, H 3.57, Br 23.12, N 4.27, P 4.65.

$\left(\Delta_{\mathrm{p}} S_{\mathrm{c}} S_{\mathrm{c}} / \Lambda_{\mathrm{P}} R_{\mathrm{c}} R_{\mathrm{c}}\right)$-6a-Hydro-2,11-dibromo-5,14-diphenyldinaphtho[2,1- $b, 2,1-h]-1,7,5,11,6$-dioxadiazaphosphaspiro[5.5] undecadiene-7a,16a (6c). M.p. ${ }^{189-192}{ }^{\circ} \mathrm{C} . \delta_{\mathrm{H}}(600.1 \mathrm{MHz}$; $\mathrm{CDCl}_{3}$; TMS) $7.54\left(1 \mathrm{H}, \mathrm{d},{ }^{1} J_{\mathrm{PH}} 852.3, \mathrm{H}_{6}\right), 5.71(2 \mathrm{H}, \mathrm{dd}$, $\left.{ }^{3} J_{\mathrm{PH}} 25.1,{ }^{3} J_{\mathrm{HH}} 6.9, \mathrm{H}_{4}, \mathrm{H}_{4^{\prime}}\right), 3.58\left(2 \mathrm{H}, \mathrm{dd},{ }^{2} J_{\mathrm{PH}} 18.1,{ }^{3} J_{\mathrm{HH}} 5.1\right.$, $\left.\mathrm{H}_{5}, \mathrm{H}_{5^{\prime}}\right) . \quad \delta_{\mathrm{P}}\left(242.9 \mathrm{MHz} ; \mathrm{CDCl}_{3} ; \mathrm{H}_{3} \mathrm{PO}_{4}\right)-81.4\left(\mathrm{~s}, \mathrm{P}_{6}\right)$. Individual substance could not be isolated.

\section{X-ray structure determination}

Data sets for single crystals of $\mathbf{4 b}$ and $5 \mathbf{a}$ were collected on Bruker AXS Kappa APEX and Smart Apex diffractometers respectively with graphite-monochromated Mo $\mathrm{K}_{\alpha}$ radiation $(\lambda=0.71073 \AA)$ using complete sphere mode. Programs used: data collection APEX2, ${ }^{68}$ data reduction 'SAINT'69 absorption correction SADABS version $2.10,{ }^{70}$ structure solution SHELXS97, ${ }^{71}$ structure refinement by full-matrix least-squares against $F^{2}$ using SHELXL-97 ${ }^{71}$, hydrogen atoms calculated and refined as riding atoms, except the hydrogens attached to phosphorus and nitrogen atoms which were located from a difference Fourier map and refined isotropically. The crystals contain solvent channels, modeled by disordered ethanol and acetone molecules. Crystals 5b contain a solvate benzene molecule, which is disordered and was refined with geometry and vibrational parameter constraints.

\section{Crystal data for $\mathbf{4 b}$}

Formula $\mathrm{C}_{34} \mathrm{H}_{27} \mathrm{~N}_{2} \mathrm{O}_{2} \mathrm{P}$, crystal size $0.39 \times 0.39 \times 0.15 \mathrm{~mm}^{3}, M=$ 526.54, orthorhombic, space group $P 2_{1} 2_{1} 2_{1}, a=8.6029(2), b=$ 15.2183(3), $c=20.4343(4) \AA, V=2675.3(1) \AA^{3}, Z=4, \rho_{\mathrm{c}}=1.307$ $\mathrm{g} \mathrm{cm}^{-3}, \mu=0.138 \mathrm{~mm}^{-1}, T=150(2) \mathrm{K}, \theta$ range $=1.67$ to $31.17^{\circ}$, reflections collected: 49141 ; independent: $8492\left(R_{\text {int }}=0.0354\right)$ and 7309 observed reflections $[I \geq 2 \sigma(I)]$, 364 refined parameters, $R_{1}=0.0406, \mathrm{w} R_{2}=0.0941[I>2 \sigma(I)]$; flack parameter $-0.03(2)$, maximal residual electron density: $0.400 /-0.229$ e $\AA^{-3}$.

\section{Crystal data for $5 a$}

Formula $\mathrm{C}_{37} \mathrm{H}_{28} \mathrm{~F}_{2} \mathrm{~N}_{2} \mathrm{O}_{2} \mathrm{P}$, crystal size $0.24 \times 0.17 \times 0.12 \mathrm{~mm}^{3}$, $M=601.58$, monoclinic, space group $C 2 / c, a=38.86(2), b=$ 8.799(5), $c=17.269(9) \AA, \beta=95.512(7)^{\circ}, V=5878(6) \AA^{3}, Z=8$, $\rho_{\mathrm{c}}=1.360 \mathrm{~g} \mathrm{~cm}^{-3}, \mu=0.144 \mathrm{~mm}^{-1}, T=293(2) \mathrm{K}, \theta$ range $=2.11$ to $26.60^{\circ}$, reflections collected: 28391 ; independent: 6119 $\left(R_{\text {int }}=0.1310\right)$ and 1891 observed reflections $[I \geq 2 \sigma(I)], 406$ refined parameters, $R_{1}=0.0440, \mathrm{w}_{2}=0.0786[I>2 \sigma(I)]$; maximal residual electron density: $0.185 /-0.193$ e $\AA^{-3}$. Due to positional disorder of the solvate benzene molecule the ratio of the observed to collected reflections is low $\sim 31 \%$.

CCDC 1542633 and 1542634 contain the supplementary crystallographic data for this paper.

\section{Notes and references}

1 K. M. Pietrusiewicz and M. Zabłocka, Chem. Rev., 1994, 94, 1375.

2 R. Noyori, in Asymmetric Catalysis in Organic Synthesis, John Wiley \& Sons, New York, 1994.

3 L. D. Quin, in A Guide to Organophosphorus Chemistry, Wiley-Interscience, New York, 2000.

4 I. Ojima, in Catalytic Asymmetric Synthesis, Wiley-VCH, New York, 2000.

5 J. Drabowicz, P. Łyźuwa, J. Omelańczuk, K. M. Pietrusiewicz and M. Mikołajczyk, Tetrahedron: Asymmetry, 1999, 10, 2757.

6 F. L. Lam, F. Y. Kwong and A. S. C. Chan, Top. Organomet. Chem., 2011, 36, 29.

7 F. H. Westheimer, Acc. Chem. Res., 1968, 1, 70.

8 S. L. Buchwald, D. H. Pliura and J. R. Knowla, J. Am. Chem. Soc., 1984, 106, 4916.

9 J. R. Knowles, Annu. Rev. Biochem., 1980, 49, 877.

10 P. J. J. M. van Ool and H. M. Buck, Recl. Trav. Chim. PaysBas, 1984, 103, 119.

11 R. R. Holmes, in Pentacoordinated Phosphorus, American Chemical Society, Washington, DC, 1980, vol. 11, p. 87.

12 D. E. C. Corbridge, in Phosphorus, Chemistry, Biochemistry and Technology, Elsevier, Amsterdam, 4th edn, 2000.

13 S. D. Lahiri, G. F. Zhang, D. Dunaway-Mariano and K. N. Allen, Science, 2003, 299, 2067.

14 G. M. Blackburn, N. H. Williams, S. J. Gamblin and S. J. Smerdon, Science, 2003, 301, 1184.

15 K. N. Allen and D. Dunaway-Mariano, Trends Biochem. Sci., 2004, 29, 495.

16 N. J. Baxter, G. M. Blackburn, J. P. Marston, A. M. Hounslow, M. J. Cliff, W. Bermel, N. H. Williams, F. Hollfelder, D. E. Wemmer and J. P. Waltho, J. Am. Chem. Soc., 2008, 130, 3952.

17 W. W. Cleland and A. C. Hengge, Chem. Rev., 2006, 106, 3252 .

18 J. A. Adams, Chem. Rev., 2001, 101, 2271.

19 M. Eder, M. Stolz, T. Wallimann and U. Schlattner, J. Biol. Chem., 2000, 275, 27094.

20 B. E. Bernstein and W. G. J. Hol, Biochemistry, 1998, 37, 4429.

21 K. Taira, T. Uchimaru, J. W. Storer, A. Yliniemela, M. Uebayashi and K. Tanabe, J. Org. Chem., 1993, 58, 3009.

22 D. M. Perreault and E. V. Anslyn, Angew. Chem., Int. Ed. Engl., 1997, 36, 432.

23 R. T. Raines, Chem. Rev., 1998, 98, 1045.

24 Y. Takagi, M. Warashina, W. J. Stec, K. Yoshinari and K. Taira, Nucleic Acids Res., 2001, 29, 1815.

25 A. C. Hengge, Acc. Chem. Res., 2002, 35, 105.

26 Z. Y. Zhang, Acc. Chem. Res., 2003, 36, 385.

27 S. D. Lahiri, G. F. Zhang, D. Dunaway-Mariano and K. N. Allen, Science, 2003, 299, 2067.

28 K. N. Allen and D. Dunaway-Mariano, Trends Biochem. Sci., 2004, 29, 495.

29 L. W. Tremblay, G. F. Zhang, J. Y. Dai, D. Dunaway-Mariano and K. N. Allen, J. Am. Chem. Soc., 2005, 127, 5298. 
30 R. R. Holmes, Acc. Chem. Res., 2004, 37, 746.

31 R. R. Holmes, Acc. Chem. Res., 1998, 31, 535.

32 N. V. Timosheva, A. Chandrasekaran and R. R. Holmes, J. Am. Chem. Soc., 2005, 127, 12474.

33 H. Fu, J. H. Xu, R. J. Wang, Z. Z. Chen, G. Z. Tu, Q. Z. Wang and Y. F. Zhao, Phosphorus, Sulfur Silicon Relat. Elem., 2003, 178, 1963.

34 G. Yang, Y. Xu, J. Hou, H. Zhang and Y. Zhao, Dalton Trans., 2010, 39, 6953.

35 G. Yang, Y. Xu, J. Hou, H. Zhang and Y. Zhao, Chem. - Eur. J., 2010, 16, 2518.

36 J. Hou, H. Zhang, J. Guo, Y. Liu, P. Xu, Y. Zhao and G. M. Blackburn, Org. Biomol. Chem., 2009, 7, 3020.

37 J. Hou, G. Tang, J. Guo, Y. Liu, H. Zhang and Y. Zhao, Tetrahedron: Asymmetry, 2009, 20, 1301.

38 S. Cao, Z. Zhou, W. Dai, P. Zhao, Y. Guo and Y. Zhao, Phosphorus, Sulfur Silicon Relat. Elem., 2015, 190, 925.

39 I. Alkorta and J. Elguero, Struct. Chem., 1998, 9, 187.

40 M. G. Chini, C. R. Jones, A. Zampella, M. V. D’Auria, B. Renga, S. Fiorucci, C. P. Butts and G. Bifulco, J. Org. Chem., 2012, 77, 1489.

41 G. Saielli, K. C. Nicolaou, A. Ortiz, H. Zhang and A. Bagno, J. Am. Chem. Soc., 2011, 133, 6072.

42 Sh. Latypov, A. Balandina, M. Boccalini, A. Matteucci, K. Usachev and S. Chimichi, Eur. J. Org. Chem., 2008, 4640.

43 S. G. Smith and J. M. Goodman, J. Am. Chem. Soc., 2010, $132,12946$.

44 G. Bifulco, P. Dambruoso, L. Gomez-Paloma and R. Riccio, Chem. Rev., 2007, 107, 3744.

45 A. Balandina, V. Mamedov, X. Franck, B. Figadere and Sh. Latypov, Tetrahedron Lett., 2004, 45, 4003.

46 A. Bagno, F. Rastrelli and G. Saielli, Chem. - Eur. J., 2006, 12, 5514.

47 B. Mikhova, B. Stamboliyska, A. Koch, H. Duddeck and E. Kleinpeter, Magn. Reson. Chem., 2008, 46, 1153.

48 F. Blanco, I. Alkorta and J. Elguero, Magn. Reson. Chem., 2007, 45, 797.

49 S. Chimichi, M. Boccalini, A. Matteucci, S. V. Kharlamov, Sh. K. Latypov and O. G. Sinyashin, Magn. Reson. Chem., 2010, 48, 607.

50 S. Klod, A. Koch and E. Kleinpeter, J. Chem. Soc., Perkin Trans. 2, 2002, 1506.

51 A. E. Aliev, Z. A. Mia, M. J. M. Busson, R. J. Fitzmaurice and S. Caddick, J. Org. Chem., 2012, 77, 6290.

52 R. M. Claramunt, D. Sanz, C. López, J. A. Jiménez, M. L. Jimeno, J. Elguero and A. Fruchier, Magn. Reson. Chem., 1997, 35, 35.

53 A. Bagno, Chem. - Eur. J., 2001, 7, 1652.

54 C. van Wüllen, Phys. Chem. Chem. Phys., 2000, 2, 2137.

55 B. Maryasin and H. Zipse, Phys. Chem. Chem. Phys., 2011, 13, 5150 .

56 Sh. K. Latypov, F. M. Polyancev, D. G. Yakhvarov and O. G. Sinyashin, Phys. Chem. Chem. Phys., 2015, 17, 6976.
57 S. Böhm, J. Tomaščiková, J. Imrich, I. Danihel, P. Kristian, A. Kochc, E. Kleinpeter and K. D. Klika, THEOCHEM, 2009, 916, 105.

58 S. G. Smith and J. M. Goodman, J. Org. Chem., 2009, 74, 4597.

59 M. J. Bartlett, P. T. Northcote, M. Lein and J. E. Harvey, J. Org. Chem., 2014, 79, 752.

60 S. Di Micco, M. G. Chini, R. Riccio and G. Bifulco, Eur. J. Org. Chem., 2010, 1411.

61 M. J. Frisch, G. W. Trucks, H. B. Schlegel, G. E. Scuseria, M. A. Robb, J. R. Cheeseman, J. A. Montgomery Jr., T. Vreven, K. N. Kudin, J. C. Burant, J. M. Millam, S. S. Iyengar, J. Tomasi, V. Barone, B. Mennucci, M. Cossi, G. Scalmani, N. Rega, G. A. Petersson, H. Nakatsuji, M. Hada, M. Ehara, K. Toyota, R. Fukuda, J. Hasegawa, M. Ishida, T. Nakajima, Y. Honda, O. Kitao, H. Nakai, M. Klene, X. Li, J. E. Knox, H. P. Hratchian, J. B. Cross, C. Adamo, J. Jaramillo, R. Gomperts, R. E. Stratmann, O. Yazyev, A. J. Austin, R. Cammi, C. Pomelli, J. W. Ochterski, P. Y. Ayala, K. Morokuma, G. A. Voth, P. Salvador, J. J. Dannenberg, V. G. Zakrzewski, S. Dapprich, A. D. Daniels, M. C. Strain, O. Farkas, D. K. Malick, A. D. Rabuck, K. Raghavachari, J. B. Foresman, J. V. Ortiz, Q. Cui, A. G. Baboul, S. Clifford, J. Cioslowski, B. B. Stefanov, G. Liu, A. Liashenko, P. Piskorz, I. Komaromi, R. L. Martin, D. J. Fox, T. Keith, M. A. Al-Laham, C. Y. Peng, A. Nanayakkara, M. Challacombe, P. M. W. Gill, B. Johnson, W. Chen, M. W. Wong, C. Gonzalez and J. A. Pople, Gaussian 03, Revision A.1, Gaussian, Inc., Pittsburgh, PA, 2003.

62 I. Szatmári, T. A. Martinek, L. Lázár, A. Koch, E. Kleinpeter, K. Neuvonen and F. Fülöp, J. Org. Chem., 2004, 69, 3645.

63 V. F. Zheltukhin, K. E. Metlushka, D. N. Sadkova, C. E. McKenna, B. A. Kashemirov and V. A. Alfonsov, Mendeleev Commun., 2007, 17, 239.

64 K. E. Metlushka, D. N. Sadkova, L. N. Shaimardanova, A. I. Tufatullin, V. F. Zheltukhin, O. N. Kataeva and V. A. Alfonsov, J. Heterocycl. Chem., 2015, 52, 80.

65 G. Bian, S. Yang, H. Huang and L. Song, Synthesis, 2013, 899.

66 C. Cardellicchio, G. Ciccarella, F. Naso, E. Schingaro and F. Scordari, Tetrahedron: Asymmetry, 1998, 9, 3667.

67 E. S. Batyeva, V. A. Alfonsov, G. U. Zamaletdinova and A. N. Pudovik, Russ. J. Gen. Chem., 1976, 46, 2204.

68 Bruker, APEX2 Software Suite for Crystallographic Programs, Bruker AXS, Inc., Madison, Wisconsin, USA, 2009.

69 Bruker, Area detector control and integration software. Version 5.x. In: SMART and SAINT, Bruker Analytical X-ray Instruments Inc., Madison, Wisconsin, USA, 1996.

70 G. M. Sheldrick, SHELX-97: Programs for Crystal Structure Analysis, Göttingen, Germany, 1997.

71 G. M. Sheldrick, Acta Crystallogr., Sect. A: Fundam. Crystallogr., 2008, 64, 112. 